Review

\title{
Recent Advances in Catalytic Synthesis of Benzosultams
}

\author{
Quan-Qing Zhao and Xiao-Qiang Hu *
}

Key Laboratory of Catalysis and Energy Materials Chemistry of Ministry of Education \& Hubei Key Laboratory of Catalysis and Materials Science, School of Chemistry and Materials Science, South-Central University for Nationalities, Wuhan 430074, China; zqqqhz@163.com

* Correspondence: huxiaoqiang@mail.scuec.edu.cn

Academic Editors: Panayiotis A. Koutentis and Andreas S. Kalogirou

Received: 3 September 2020; Accepted: 21 September 2020; Published: 23 September 2020

\begin{abstract}
Benzosultams represent one category of multi-heteroatom heterocyclic scaffolds, which have been frequently found in pharmaceuticals, agricultural agents, and chiral catalysts. Given the diversely significant functions of these compounds in organic and medicinal chemistry, great efforts have been made to develop novel catalytic systems for the efficient construction of benzosultam motifs over the past decades. Herein, in this review, we mainly summarize the recent advances in the field of catalytic synthesis of benzosultams from 2017 to August of 2020, with an emphasis on the scopes and mechanisms of representative reactions.
\end{abstract}

Keywords: sulfonamides; benzosultams; $\mathrm{C}-\mathrm{H}$ activation; photoredox catalysis; cascade reaction

\section{Introduction}

Sulfonamides constitute one of the most important antibiotics developed from non-natural sources [1,2]. Benzosultams, a subclass of bicyclic sulfonamides, are found in numerous biologically active compounds, pharmaceuticals, as well as agricultural agents [3-7]. They exhibit a wide spectrum of promising bioactivities, such as antibacterial, antidiabetic, anticancer, and vitro HPPD (4-hydroxyphenylpyruvate dioxygenase) inhibitory activities, which have been widely utilized as inhibitors and drugs [8-12]. Representative examples have been outlined in Scheme 1. Moreover, benzosultams can be employed as chiral auxiliaries in asymmetric synthesis [13]. They are also versatile building blocks for the assembly of a variety of diversely functionalized benzosultam derivatives and other heterocyclic systems. In this context, various transformations have been developed, such as dipolar cycloaddition [14,15], nucleophilic addition [16-21], transition metal-catalyzed C-H activation/annulation [22-25], Corey-Bakshi-Shibata reduction, and Aza-Darzens condensation [26,27] etc., which extensively expand their application range in the area of synthetic chemistry. Therefore, the development of convenient methods for the efficient preparation of benzosultams play important roles in drug discovery and asymmetric synthesis, which have attracted much attention from synthetic chemists.

Traditionally, benzosultam scaffolds can be readily constructed from some specialized substrates in one step, such as intramolecular C-H amination [28], dipolar cycloaddition [29], and intramolecular Michael addition [30]. In addition, multi-component or -step reactions have also been developed to prepare these important compounds [31-39]. In recent years, the exploration of catalytic methods enabled by transition metal or organic catalysis has been established as a robust tool for the synthesis of benzosultams in an efficient and region-divergent fashion. Taking advantage of the high and unique reactivity of free radicals, the radical-induced synthetic strategy has also been applied to construct benzosultams. Mondal et al. successively summarized the advances in sultam synthesis, biological 
activities, and synthetic applications (2000-2010, 2011-June 2017) [40,41]. In 2020, Grygorenko and colleagues comprehensively discussed the recent developments in the synthesis of saturated bicyclic sultams [42]. Taking into account the significance of benzosultam scaffolds, in this review, we provide an overview of catalytic synthesis of benzosultams from 2017 to August of 2020, with an emphasis on catalytic models, substrate scopes, and reaction mechanisms. Based on different catalytic modes, the discussion is mainly classified into two sections, including transition metal-catalyzed benzosultam synthesis and visible light photocatalytic benzosultam synthesis. Of note, visible light-induced catalytic synthesis, rarely covered in previous reviews, will be discussed here in detail. These reactions in which benzosultams are employed as starting materials for further transformations will not be discussed here.

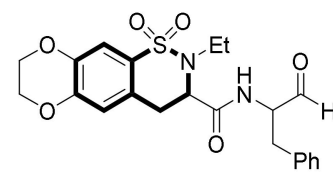

Calpain I inhibitor<smiles>CN1c2c(oc(=O)n(-c3ccccc3)c2=O)-c2ccccc2S1(=O)=O</smiles>
Droxicam (Drug)<smiles>[R]n1c2c(c(=O)n([R])c1=O)N(C)S(=O)(=O)c1ccccc1-2</smiles>

$$
\mathrm{R}=\mathrm{Me}, \mathrm{Et}
$$

Antibacterial activity

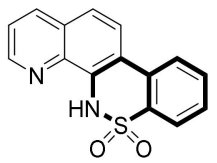

NF-KB inhibitor

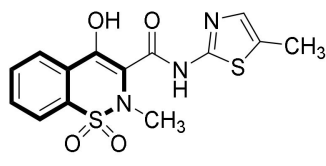

Meloxicam (Drug)

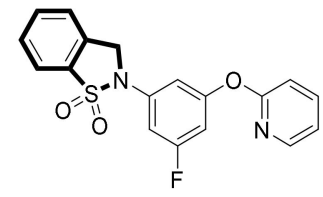

Antidiabetic activity

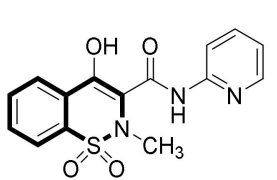

Piroxicam (Drug)

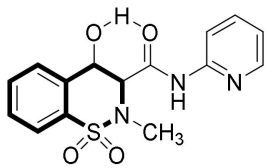

Piroxicam (Drug)

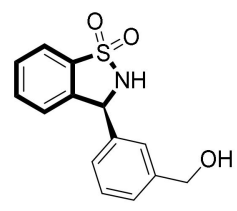

HIV-1 inhibitor
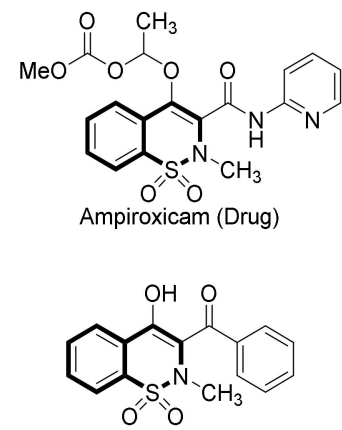

Vitro HPPD inhibitory activity

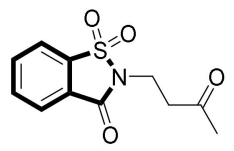

Saccharin

Scheme 1. Selected examples of biologically important benzosultams.

\section{Transition Metal-Catalyzed Benzosultam Synthesis}

\subsection{Synthesis of Benzosultams via $C\left(s p^{2}\right)-H$ Functionalization}

Over the past several decades, transition metal (Fe, $\mathrm{Co}, \mathrm{Ni}, \mathrm{Ru}, \mathrm{Rh}, \mathrm{Pd}, \mathrm{Ir}$, and $\mathrm{Pt}$ )-catalyzed $\mathrm{C}-\mathrm{H}$ activation and subsequent functionalization have been intensively investigated and established a powerful tool for the construction of structurally diverse heterocycles [43-49]. In 2010, Urabe and co-workers developed a palladium-catalyzed $\mathrm{C}-\mathrm{H}$ activation/cyclization reaction of $Z$-bromoalkenes for the synthesis of benzosultams. It should be noted that the Z-bromoalkenes can be easily synthesized from the nucleophilic addition of $N$-alkyl- $p$-toluenesulfonamides to bromoacetylenes [50]. Later, Mondal and co-workers further applied this strategy into an intramolecular cyclization of aryl bromides for the regioselective formation of uracil-, coumarin-, and quinolone-fused benzosultams [51]. Using three equivalents of AgOAc as the efficient oxidant, in 2014, Laha et al. demonstrated a Pd-promoted intramolecular oxidative coupling reaction of sulfonanilides, which offers a facile access to a range of biaryl sultams [52]. This protocol could be applied to the preparation of seven-membered biaryl sultams and biaryl sultones. The same strategy has been further used in the intramolecular oxidative coupling of $\mathrm{N}$-arylsulfonyl heterocycles, such as $\mathrm{N}$-arylsulfonyl indoles and pyrroles, producing heterobiaryl sultams in generally good yields [53], which may provide new opportunities in drug discovery. In addition, in the presence of amines, NaOEt, or Grignard reagents as nucleophiles, the ring opening of indole-fused benzosultams has been achieved for the preparation of heterobiaryls.

Inspired by these works, in 2017, Laha et al. systematically investigated the intramolecular oxidative coupling of diversely substituted $\mathrm{N}$-arylsulfonyl pyrroles, delivering a variety of pyrrole-fused 
benzosultams 2 with good region selectivity (Scheme 2a) [54]. In this protocol, $N$-arylsulfonyl pyrrole 1 bearing a sensitive 3-bromo group was tolerated, albeit with the depression of reaction efficiency. Compared to indole-fused benzosultams, the ring opening of pyrrole-fused benzosultams turned out to be difficult and the introduction of an electron-withdrawing group at the C-2 position can significantly improve the reaction efficiency. To further broaden the synthetic utility of this strategy, the late-stage diversification of pyrrole-fused benzosultams has been investigated (Scheme 2b). Suzuki coupling reaction of pyrrole-fused benzosultam $\mathbf{2} \mathbf{e}$ with arylborates proceeded smoothly to afford the fluorene tethered compound 4 in a $70 \%$ yield. The absorption and photoluminescence spectra of 4 displayed $\lambda_{\max }$ at $321 \mathrm{~nm}$ and $\lambda_{\text {emission }}$ at $456 \mathrm{~nm}$ in dichloromethane, respectively, which has tremendous application potential in organic light-emitting devices (OLEDs) [55].
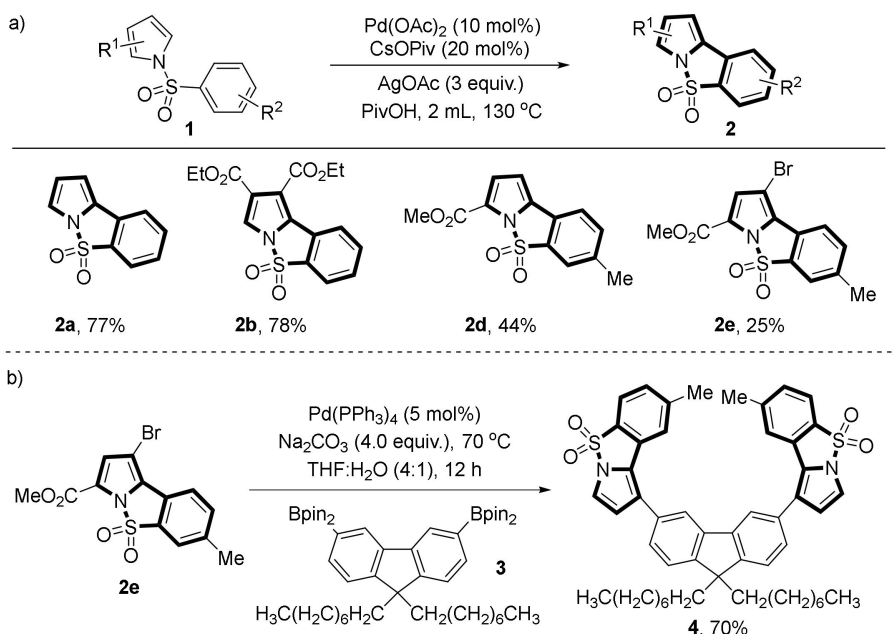

Scheme 2. (a) Palladium-catalyzed synthesis of pyrrole-fused benzosultams; (b) Synthetic transformation.

Later, Wang et al. discovered a $\mathrm{Pd}(\mathrm{II})$-catalyzed cyclization of bioactive peptidosulfonamides through peptide-guided C-H activation (Scheme 3) [56]. The peptides acted as internal directing groups in this reaction, which enabled the selective cyclization of benzosulfonamides 5 and macrocyclization of peptidosulfonamides 8 . Under the reaction conditions, a variety of benzosultam-peptidomimetics 7 and peptidosulfonamide macrocycles 9 could be furnished in moderate to good yields. The potential utility of this methodology was demonstrated by the successful synthesis of a fluorescent-labeled cyclic RGD (Arg-Gly-Asp) peptide, which exhibits strong binding affinity towards integrins [57].

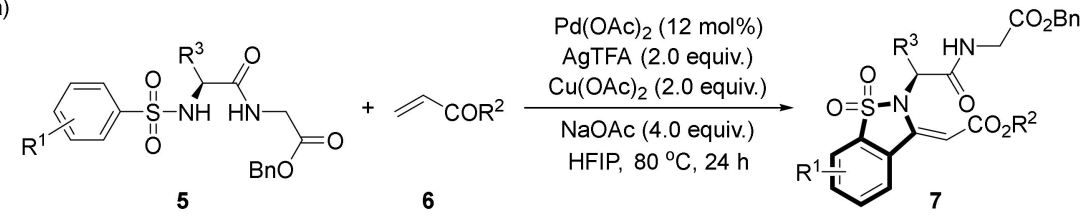

b)

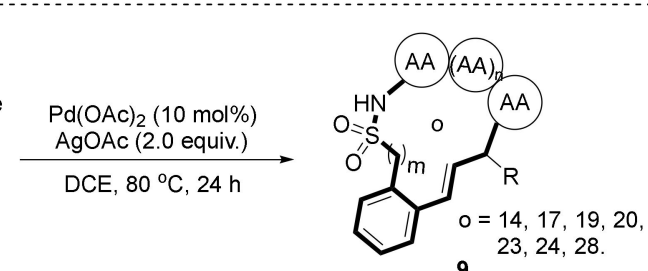

Scheme 3. (a) Palladium-catalyzed synthesis of benzosultam-dipeptide conjugates; (b) Synthesis of peptidosulfonamide macrocycles. 
Mechanistic studies indicated the involvement of a reactive dipeptide-Pd(II) complex 5-E in this transformation. As outlined in Scheme 4, the reaction starts with the formation of Pd(II)-complex 5-A via $\mathrm{Pd}(\mathrm{II})$-catalyzed $\mathrm{C}-\mathrm{H}$ activation directed by the $\mathrm{N}$-sulfonated peptide. Then, the coordination of intermediate 5-A with olefin 6 generates complex 5-B, which undergoes a 1, 2-migratory insertion process, followed by a $\beta$-hydride elimination to provide olefination intermediate 5 -D. In the presence of $\mathrm{Pd}(\mathrm{II})$-catalyst, the resulting intermediate 5-D performs another $\mathrm{C}-\mathrm{H}$ activation, providing the key intermediate 5-E. The structure of 5-E was unambiguously confirmed by X-ray analysis. Finally, reductive elimination of 5-E produces the desired product along with the formation of $\operatorname{Pd}(0)$-catalyst. The reoxidation of $\mathrm{Pd}(0)$-catalyst by $\mathrm{Ag}(\mathrm{I})$ or $\mathrm{Cu}(\mathrm{II})$ species could regenerate the active $\mathrm{X}_{2} \mathrm{Pd}(\mathrm{II}) \mathrm{L}_{n}$ catalyst for the next catalytic cycle.

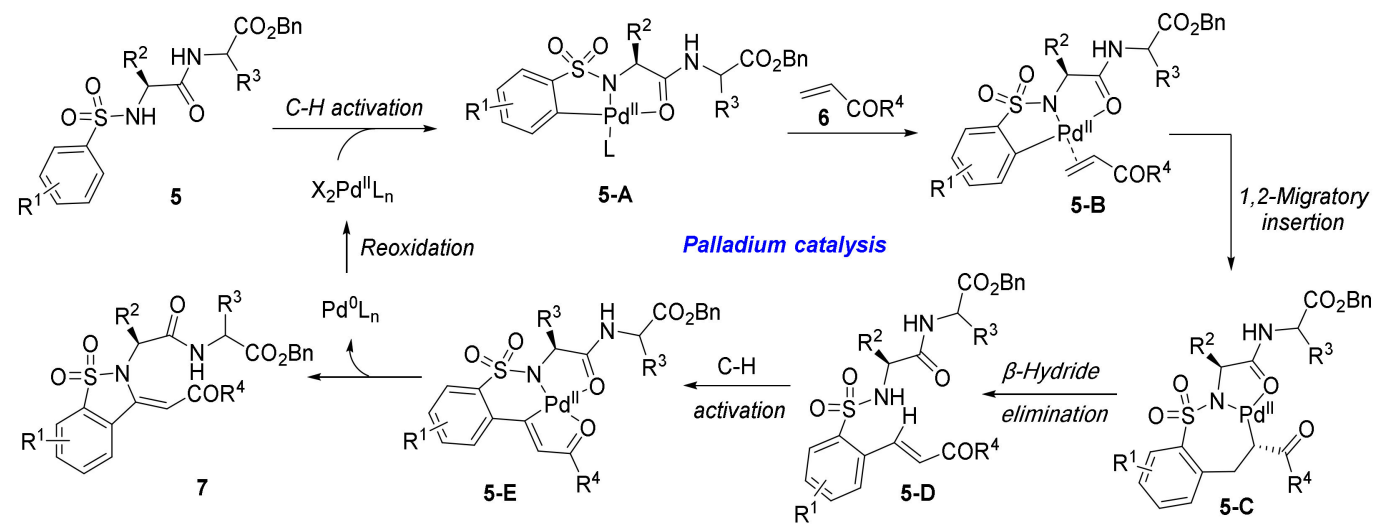

Scheme 4. Plausible mechanism of self-guided functionalization of peptidosulfonamides.

Rhodium-catalyzed C-H activation/cyclization provides an alternative method for the assembly of heterocycles [43]. In 2012, Cramer and co-workers reported the first example of Rh(III)-catalyzed C-H activation of acylated sulfonamides and subsequent coupling with alkynes, delivering a broad range of six-membered cyclic benzosultams in generally good yields [58]. Then, Li and Wang et al. extended this strategy to the oxidative coupling of $N$-tosylacetamide with various acrylate esters for the preparation of five-membered cyclic benzosultams [59]. Using $\mathrm{RuCl}_{3}$ as an efficient catalyst, in 2018, You and colleagues disclosed a direct oxidative $\mathrm{C}-\mathrm{H} / \mathrm{C}-\mathrm{H}$ cross-coupling of (hetero)aromatic sulfonamides with a series of (hetero)arenes for the synthesis of ortho-sulfonamido bi(hetero)aryls [60]. The obtained bi(hetero)aryl sulfonamides could be conveniently transferred into benzosultam derivatives in two steps.

Encouraged by these works, Chen and co-workers achieved a rhodium-catalyzed ortho-alkynylation or alkynylation/cyclization of arylsulfonamides, synthesizing an array of aryl sulfonamides and benzosultams (Scheme 5) [61]. The substituent in bromoalkyne has a significant effect on this reaction. When (triisopropylsilyl)ethynyl bromide was used as the substrate, the corresponding ortho-(1-alkynyl) benzenesulfonamides could be obtained. Interestingly, using triethyl (TES) or trimethyl (TMS) protected bromoacetylenes as coupling regents, a cascade ortho-alkynylation/cyclization of arylsulfonamides could occur to give six-membered benzosultams (Scheme 5a). One impressive feature of this reaction is the broad substrate scope. Aryl sulfonamides bearing an electron-donating or -withdrawing group at different positions were well-tolerated in this reaction. It is noteworthy that the protecting groups could be readily removed from benzosultam products in the presence of tetra- $n$-butylammonium fluoride (TBAF), enlarging the application range of these reactions (Scheme $5 b$ ). In addition, the gram-scale reaction was also successful. 
a)
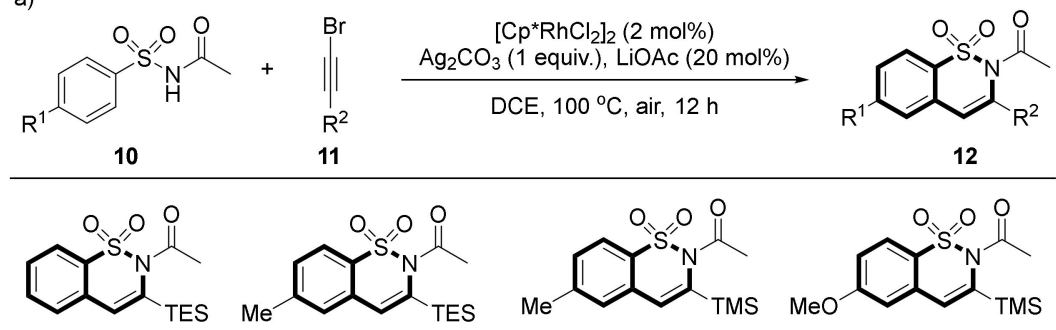

$12 \mathrm{a}, 79 \%$

12b, $75 \%$

12c, $71 \%$

12d, $68 \%$

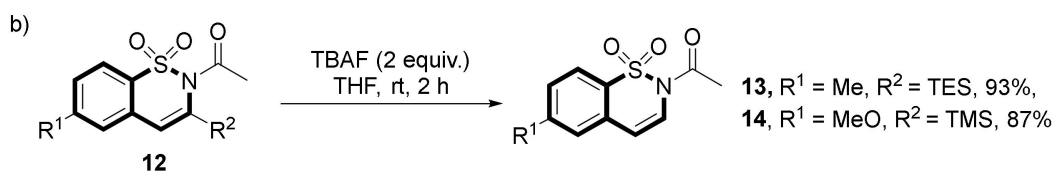

Scheme 5. (a) Rhodium-catalyzed C-H alkynylation/cyclization of acylated sulfonamides; (b) Synthetic transformation.

Mechanistic studies revealed the Rh-catalyzed ortho-C-H cleavage was the rate determining step in this reaction. The coordination of $\mathrm{Ru}(\mathrm{III})$-catalyst with arylsulfonamide affords a five-membered rhodacycle species 10-B via ortho-C-H activation (Scheme 6). Then, the dissociative ligand exchange of 10-B with 11 results in 10-C, which undergoes an alkyne insertion process to provide 10-D. The subsequent elimination of Br-atom of intermediate 10-E by AgOAc produces complex 10-F, followed by ligand exchange with substrate $\mathbf{1 0}$ to deliver the product and regenerate rhodacycle complex 10-B.

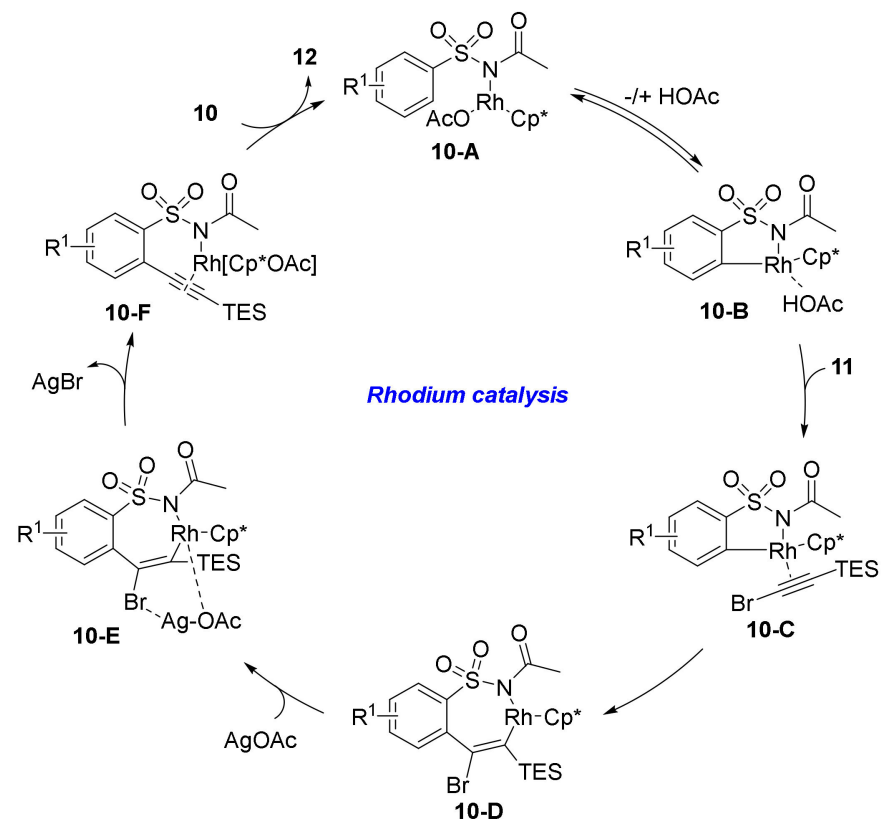

Scheme 6. Proposed mechanism for rhodium-catalyzed C-H alkynylation/cyclization.

Despite the impressive achievements in the synthesis of intriguing five- or six-membered sulfonamide-fused skeletons, the development of efficient methods for the assembly of larger macrocyclic ring frameworks remain largely unexplored and a challenging task for synthetic chemists. In 2020, Zhou and Yi et al. discovered an Rh-catalyzed intramolecular dehydrogenative annulation of 2-alkenylanilides to give various eight-membered benzosultams with an excellent chemoselectivity through PivOH-assisted $\mathrm{C}-\mathrm{H}$ activation and the $\mathrm{H}$-transfer process (Scheme 7) [62]. It was found that the rational combination of $\left[C \mathrm{p}^{* C y} \mathrm{RhCl}_{2}\right]_{2}$ catalyst and KOPiv can efficiently promote this 
transformation. This catalytic system was effective for intramolecular dehydrogenative cyclization of $N$-(2-vinylphenyl)benzamides, furnishing the corresponding eight-membered lactams in moderate yields. Mechanistic investigations by density functional theory (DFT) calculations and control experiments suggested the $\mathrm{Rh}(\mathrm{III})$-hydride species was the active catalyst in this reaction. In addition, $\mathrm{H}_{2}$ proved to be the major byproduct by $\mathrm{PdCl}_{2}$ testing paper. Alternatively, cobalt-catalyzed aryl $\mathrm{C}\left(\mathrm{sp}^{2}\right)-\mathrm{H}$ activation/annulation have also been developed for the construction of benzosultam scaffolds. For instance, Sundararaju and Volla et al. independently developed Co-catalyzed C-H activation/N-H cyclization of sulfonamides with the use of alkynes or allenes as coupling partners, yielding a variety of biologically interesting benzosultam motifs $[63,64]$. These works have been covered in a previous review, which were not discussed in detail here [41].

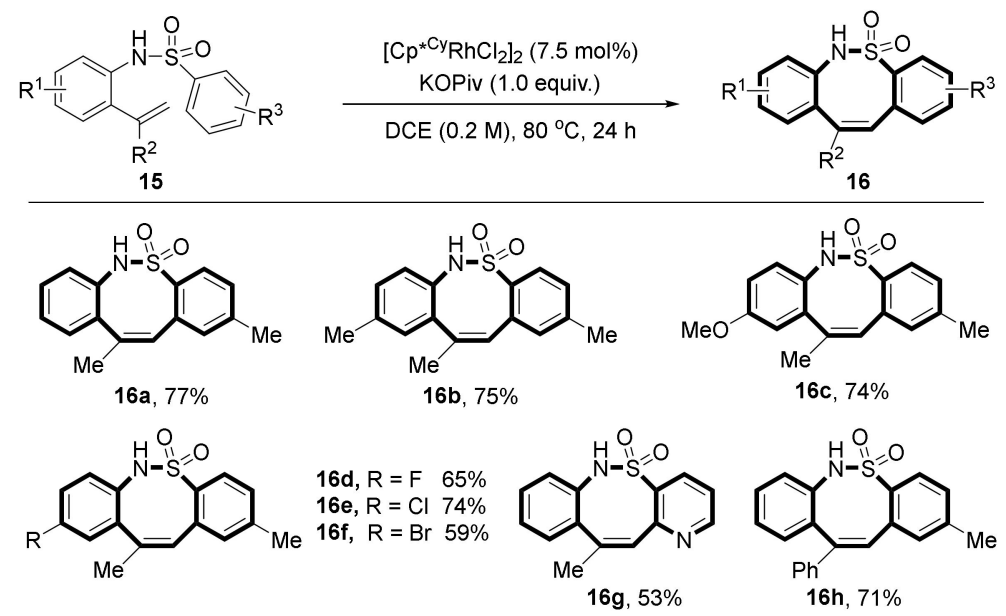

Scheme 7. Rhodium-catalyzed dehydrogenative cross-couplings for benzosultams.

Benzo- $\gamma$-sultam represents a quite unusual type of benzosultams, which is a key structural motif in ORL1-receptor (opioid receptor-like 1) antagonists, which have been used for the treatment of pain and CNS (central nervous system) disorders. In addition, benzo- $\gamma$-sultams can also be regarded as versatile building blocks for the preparation of heterocycles through the generation of reactive aza-ortho-xylylene species by thermal extrusion of $\mathrm{SO}_{2}$ [65]. Early in 1963, Bunnett and co-workers firstly synthesized benzo- $\gamma$-sultams via an intramolecular ring closure of $N$ - $2^{\prime}$-chloroaryl alkanesulfonamides under strongly basic conditions [66]. Since then, great efforts have been devoted into this interesting field [67,68]. In 2014, Xu et al. developed an Rh-catalyzed intramolecular C $\left(\mathrm{sp}^{2}\right)-\mathrm{H}$ insertion of $N, N$-diaryl diazosulfonamides, providing $N$-aryl-substituted benzo- $\gamma$-sultams in moderate to good yields (Scheme 8a) [69]. Outstanding features of this protocol include high efficiency and low catalyst loading $(0.5 \mathrm{~mol} \%)$. However, this rhodium-mediated catalytic system turned out to be ineffective for $\mathrm{N}$-alkyl-N-aryl diazosulfonamide substrates. Afterwards, $\mathrm{Xu}$ and Yang et al. addressed this problem with the use of an inexpensive copper-catalyst in reflux toluene (Scheme 8b) [70]. 
a)
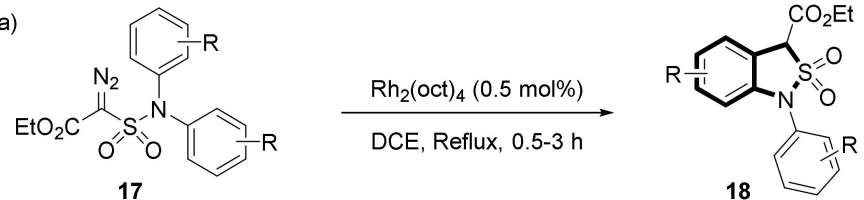

b)
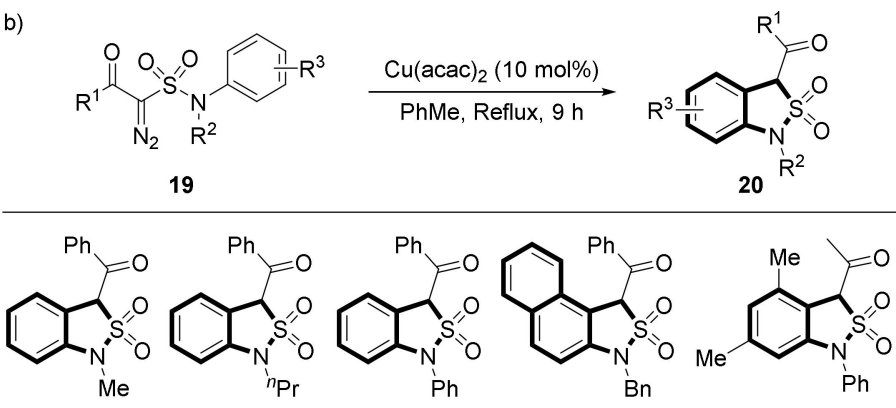

20 a, $40 \% \quad 20$ b, $47 \% \quad$ 20c, $59 \%$

20d, $30 \%$

20 e, $37 \%$

Scheme 8. (a) Rh-catalyzed synthesis of benzo- $\gamma$-sultams; (b) Cu-catalyzed synthesis of benzo- $\gamma$-sultams.

\subsection{Synthesis of Benzosultams via $C\left(s p^{3}\right)-H$ Amination}

The selective functionalization of $\mathrm{C}\left(\mathrm{sp}^{3}\right)-\mathrm{H}$ bonds is one of the most attractive methods for molecular construction in modern synthesis. However, the activation of inert $\mathrm{C}\left(\mathrm{sp}^{3}\right)-\mathrm{H}$ bonds remains a fundamental challenge for the synthetic community due to their robust bond energy [49,71]. In 2007, Zhang's group firstly developed an efficient Co-based catalytic system for the intramolecular $\mathrm{C}\left(\mathrm{sp}^{3}\right)-\mathrm{H}$ amination with arylsulfonyl azides, resulting in a range of highly valuable benzosultams under mild conditions [72]. Primary, secondary, and tertiary $\mathrm{C}-\mathrm{H}$ bonds were compatible with this catalytic system. In 2010, Zhang et al. further applied this concept to the amination of sulfamoyl azides for the high-yielding preparation of cyclic sulfamides [73].

Very recently, the asymmetric variants of intramolecular $\mathrm{C}\left(\mathrm{sp}^{3}\right)-\mathrm{H}$ amination have been achieved by the same group with the use of $\mathrm{Co}$ (II)-catalysts of $\mathrm{D}_{2}$-symmetric amidoporphyrins, producing five-membered chiral cyclic benzosultams in good yields with high enantioselectivities (Scheme 9) [74]. Importantly, this reaction can be scaled up to $10 \mathrm{mmol}$ to give the desired product without affecting reaction efficiency. In addition, this methodology was successfully applied in the concise synthesis of a chiral-fused-tricyclic sulfonamide target, which exhibits a broad range of enzyme inhibitory properties. These applications nicely demonstrated the practicality and synthetic utility of this $1,5-\mathrm{C}-\mathrm{H}$ amination reaction. A series of mechanistic studies have been conducted to investigate the unique metalloradical mechanism of this reaction. The results of EPR experiments demonstrated the intermediacy of a $\alpha$-Co(III)-aminyl radical in this transformation. The high value of the intramolecular kinetic isotopic effect (KIE) suggested that the cleavage of $\mathrm{C}\left(\mathrm{sp}^{3}\right)-\mathrm{H}$ bonds was realized through $\mathrm{H}$-atom abstraction by $\alpha-\mathrm{Co}(\mathrm{III})$-aminyl radical species. On the basis of these results, a plausible mechanism is proposed in Scheme $9 \mathrm{~b}$. Initially, cobalt catalyst reacts with sulfonyl azides 21 to generate $\alpha$-Co(III)-aminyl radical 21-A. Then, the species 21-A undergoes a 1,5-H atom abstraction to afford $\varepsilon$-Co(III)-alkyl radical 21-B, followed by a radical substitution step to give the final product. 
a)
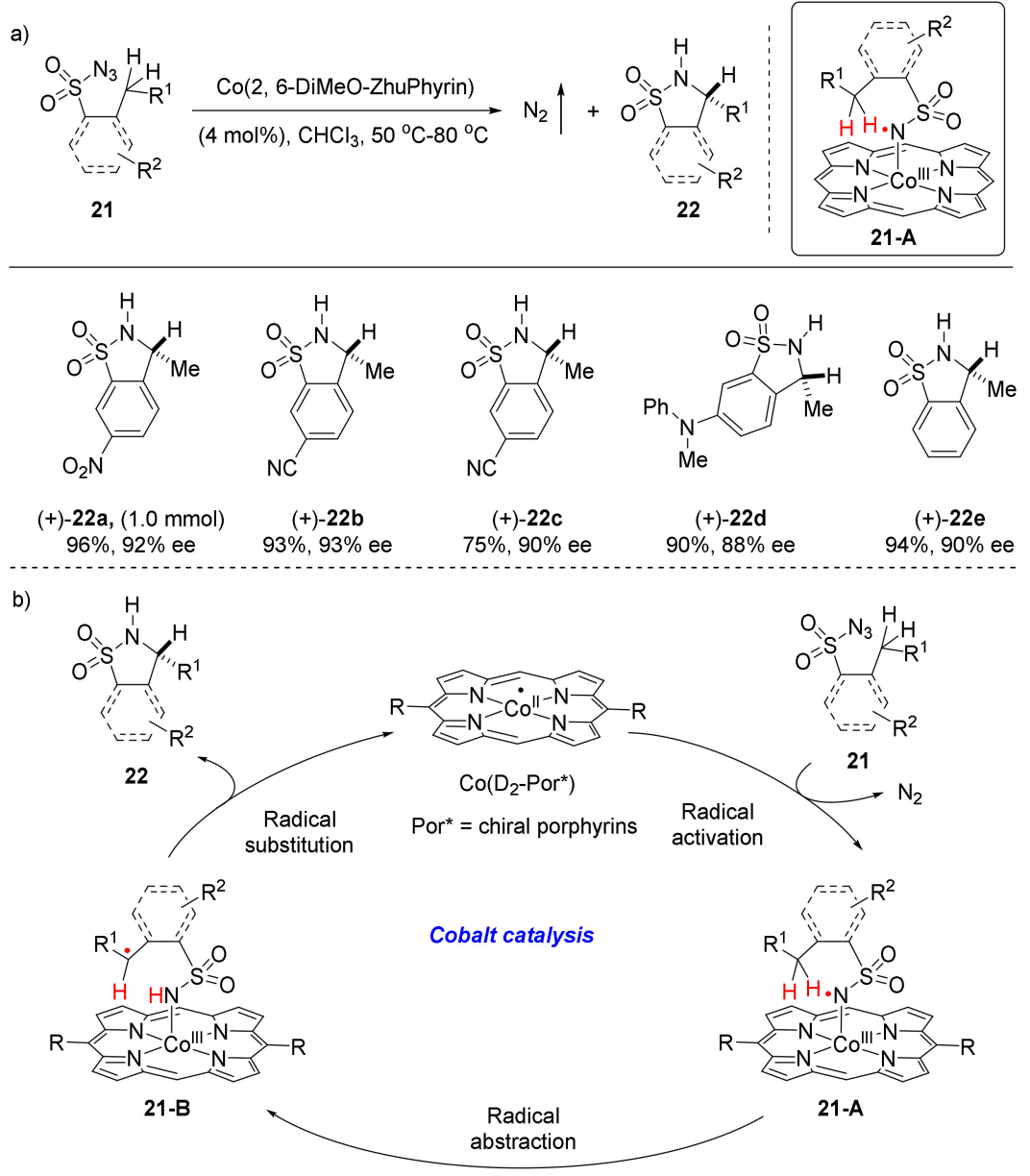

Scheme 9. (a) Cobalt-catalyzed asymmetric $\mathrm{C}\left(\mathrm{sp}^{3}\right)-\mathrm{H}$ amination of arylsulfonyl azides; (b)

Proposed mechanism

Cytochrome P450 enzymes, produced from thermophilic organisms, represent a huge family of oxidative hemoproteins, which have been often applied in oxygen-atom transfer reactions [75-77]. Arnold and Fasan et al. independently found that cytochrome P450 enzymes can be used as efficient nitrene transfer catalysts to promote intramolecular $\mathrm{C}\left(\mathrm{sp}^{3}\right)-\mathrm{H}$ amination with sulfonylazides for the synthesis of benzosultams with good enantioselectivities [78-82]. However, among these reactions, the yields of amination products are relatively low due to the competing reduction of sulfonyl azides to sulfonamides. Recently, Hartwig et al. utilized artificial cytochrome P450 enzymes, containing an iridium porphyrin cofactor ( $\operatorname{Ir}(\mathrm{Me})-\mathrm{PIX})$, as an efficient catalyst to realize the insertion of nitrene into the $\mathrm{C}\left(\mathrm{sp}^{3}\right)-\mathrm{H}$ bond with excellent chemoselectivity over the reduction of sulfonyl azides (Scheme 10) [83]. Of note, the change of the active site in $\mathrm{P} 450$ enzyme from iron to non-native metal iridium creates a highly active catalyst for chemoselective $\mathrm{C}-\mathrm{H}$ amination. Under mild conditions, the desired benzosultams can be obtained in up to a $98 \%$ yield and 294 TON (turnover number). 
a)

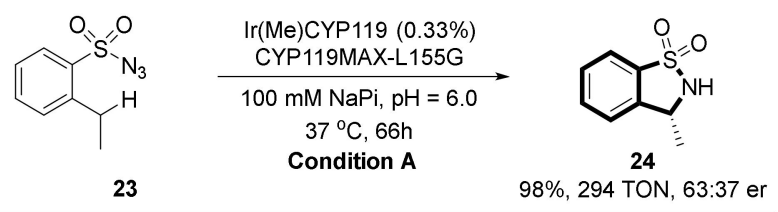

b) Condition B: $0.33 \mathrm{~mol} \% \operatorname{Ir}(\mathrm{Me})-\mathrm{PIX}$ CYP119 (mutations C317G, T213G, V254L, F310G)
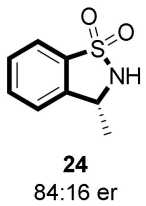

67\%, 201 TON

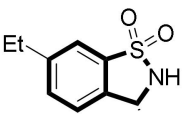

25

95:5 e

$64 \%, 192$ TON

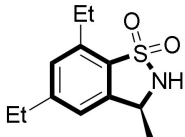

26

84:16 er 129 TON

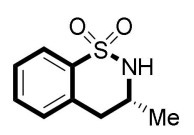

27

$84: 16$ er 126 TON

Scheme 10. (a) Cytochrome P450-catalyzed synthesis of chiral benzosultams under condition A;

(b) Synthesis of chiral benzosultams under condition B.

More recently, Schomaker and co-workers developed a silver-catalyzed nitrene transfer for the amination of $\mathrm{C}\left(\mathrm{sp}^{3}\right)-\mathrm{H}$ bonds (Scheme 11) [84], providing a series of five- and six-membered benzosultams. The regioselective differentiation of vicinal methylene $\mathrm{C}\left(\mathrm{sp}^{3}\right)-\mathrm{H}$ bonds could be achieved via electronic and steric control. The amination of homobenzylic methylene $\mathrm{C}-\mathrm{H}$ bonds proved to be more preferential than their benzylic methylene neighbors. For alkyl-substituted benzenesulphonamides, six-membered benzosultams can be obtained as the main products. Moreover, when $\gamma$-branched alkyl substituents were used as the substrates, ligand-controlled tunable regioselectivity was observed for the synthesis of five- or six-membered benzosultams. It is noted that this reaction should be protected from light with Al foil and the yield of products can be significantly improved in the absence of light.
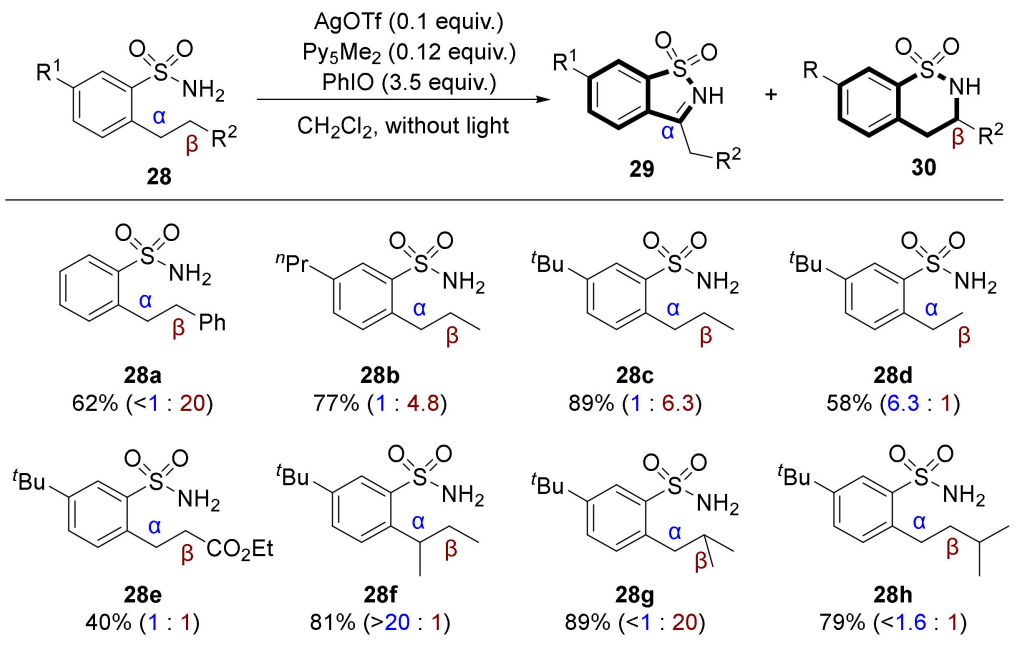

Scheme 11. Silver-catalyzed nitrene insertion of $\mathrm{C}\left(\mathrm{sp}^{3}\right)-\mathrm{H}$ bonds for benzosultam synthesis.

\subsection{Synthesis of Benzosultams via Hydroamination of Alkyne}

Transition metal-mediated hydroamination of alkyne provides a powerful platform for the formation of $\mathrm{C}-\mathrm{N}$ bonds, which has found widespread applications in the synthesis of various biologically important heterocycles [85,86]. In 2015, Mondal and co-workers developed an elegant $\mathrm{Pd} / \mathrm{Cu}$-catalyzed one-pot Sonogashira coupling/hydroamination cascade of 2-bromobenzenesulfonamides with terminal alkynes, providing an alternative access to benzosultams [87]. In addition, Zhu et al. finished the synthesis of a variety of indole-fused benzosultams via Pd(II)-catalyzed diamination of alkynes [88]. 
In 2018, Mondal and co-workers further extended their one-pot process towards the construction of indole-fused seven-membered benzosultams from easily available starting materials (Scheme 12) [89]. The synergistic combination of $\mathrm{Pd}\left(\mathrm{PPh}_{3}\right)_{2} \mathrm{Cl}_{2}$ and $\mathrm{CuI}$ catalysts in DMF was found to be crucial for high reaction conversion. Under the optimal conditions, a variety of indole-fused benzosultams were obtained in good yields. In addition, the role of the $N$-protecting group in $o$-iodoanilines has been investigated. It should be noted that $N$-mesylated $o$-iodoanilines produced the free indolyl nitrogen-containing benzosultams, while N-unsubstituted-o-anilines failed to give the cylization products. The plausible mechanism is outlined in Scheme 12. Firstly, a Pd/Cu-catalyzed Sonogashira coupling reaction occurs between $o$-iodoaniline 31 and propargylsulfonamides 32 to yield intermediate 32-A. Then, the $\mathrm{Cu}(\mathrm{I})$-catalyst may coordinate with alkynyl and sulfone groups to produce complex 32-B, which undergoes an intramolecular nucleophilic attack to give intermediate 32-C. The resultant intermediate further proceeded an oxidative addition, intramolecular arylation, and reductive elimination sequence to generate intermediate 32-F, followed by a deprotonation process to give the final product.

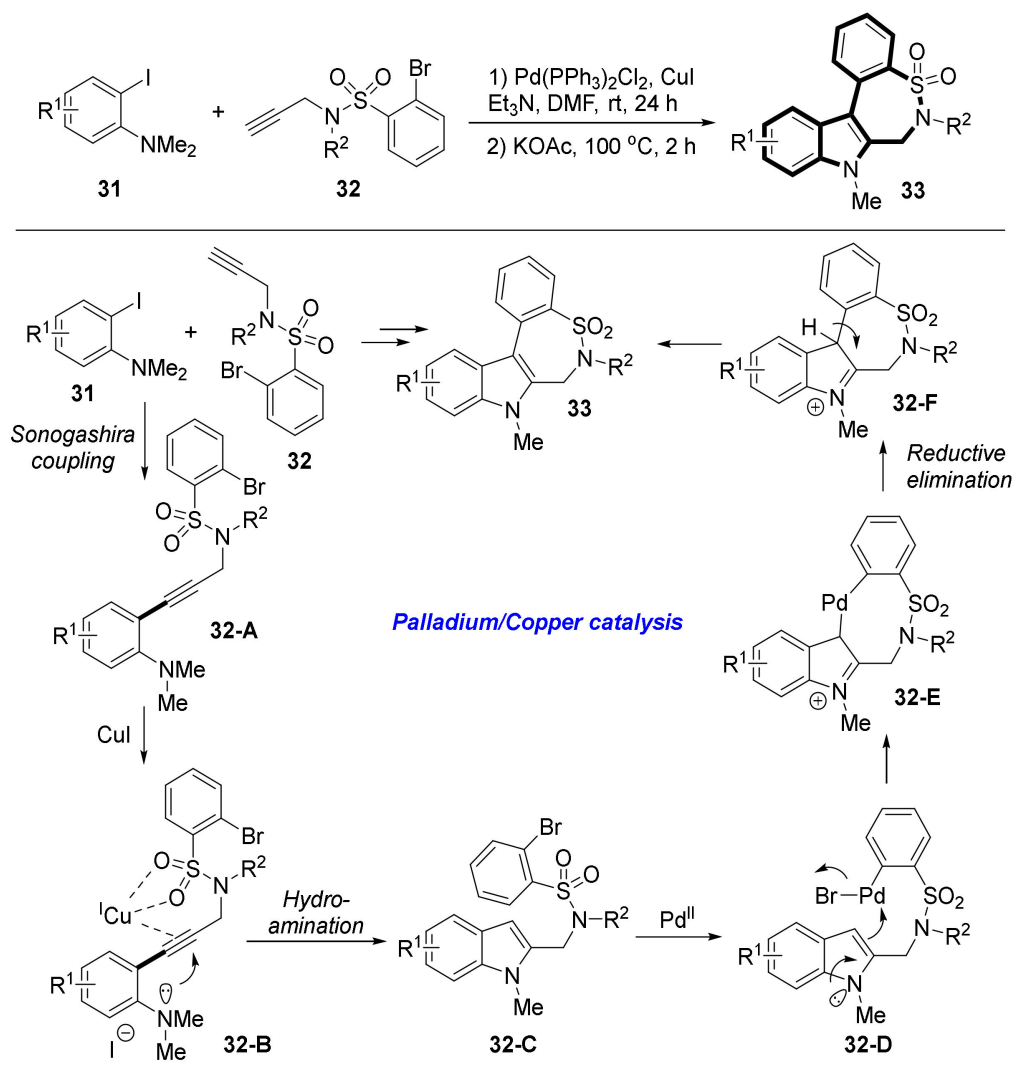

Scheme 12. Palladium-catalyzed one-pot synthesis of indole-fused benzosultams.

With the assistance of a catalytic amount of silver catalyst $\left(\mathrm{AgSbF}_{6}\right)$, Reddy and co-workers firstly synthesized a series of fused benzo- $\delta$-sultams from alkynols and aldehydes via silver-promoted hydroamination/Prins-type cyclization strategy (Scheme 13) [90]. The selection of a catalyst is critical for the success of this reaction and $\mathrm{AgSbF}_{6}$ proved to be the most preferable catalyst. Other Lewis acids $\left(\mathrm{In}(\mathrm{OTf})_{3}, \mathrm{FeCl}_{3}, \mathrm{TMSOTf}\right.$, and $\left.\mathrm{Sc}(\mathrm{OTf})_{3}\right)$ or Brønsted acids ( $p$-TSA and TFA) failed to promote this transformation. A range of aliphatic and (hetero)aromatic aldehydes were suitable for this reaction, giving the expected compounds in moderate to good yields. Generally, (hetero)aromatic aldehydes delivered the products in higher yields than aliphatic aldehydes. Remarkably, the acid-sensitive cinnamaldehyde was well-tolerated in this reaction to give the corresponding product in excellent yield. This reaction provides a facile and straightforward access to fused benzo- $\delta$-sultams. The reaction mechanism initially starts with the coordination of $\mathrm{Ag}(\mathrm{I})$-catalyst with the alkyne group, producing 
an Ag- $\pi$ complex 34-A (Scheme 13b). An intramolecular 6-endo-dig cyclization of intermediate 34-A occurs to form the intermediate 34-B. A condensation reaction between 34-B and aldehyde affords the reactive $0 x_{0}$-carbenium ion species 34-C, followed by a Prins-type cyclization to give the final products 36 .

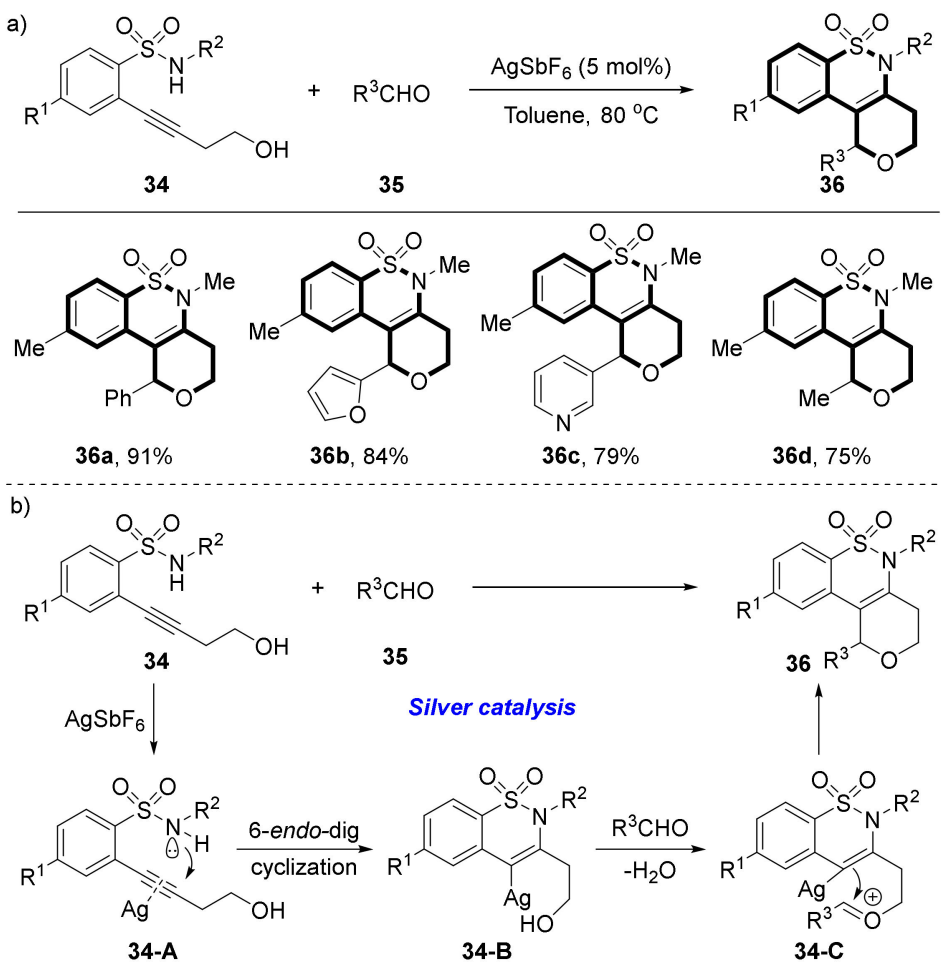

Scheme 13. (a) Silver-catalyzed intramolecular annulation cascade for benzosultams; (b) Proposed mechanism.

Very recently, Blanc and co-workers developed a convenient approach to benzosultams from $N$-(2-alkynyl)-phenylsulfonyl azetidines and nucleophilic alcohols through a gold(I)-mediated cyclization/nucleophilic substitution process (Scheme 14) [91]. A variety of alkyl alcohols were compatible with this catalytic system. However, phenol was unable to proceed this reaction due to its weak nucleophilicity. Notably, indole, a C-based nucleophile, could also provide the corresponding product 38e at an elevated temperature. Other strong nucleophiles, such as amines and thiols, were unsuccessful substrates for this reaction, which may cause the deactivation of gold(I)-catalyst. When terminal alkyne was subjected into this reaction at $70^{\circ} \mathrm{C}$, the unexpected product 39 was observed.

Mechanistic investigations, including blank and isotopic labeling experiments, revealed that the spiroammonium intermediate $\mathbf{3 7 - B}$ is a plausible intermediate in this reaction. Moreover, the intermediate 37-B can be easily trapped by $\mathrm{N}$-iodosuccinimide (NIS) to deliver 4-iodobenzosultams, which subsequently participated in cross-coupling reactions for the facile construction of highly functionalized benzosultams. As described in Scheme 14b, the activation of acetylenic moiety by gold(I)-catalyst generates species 37-A, which reacted with sulfamide fragment to give spiroammonium 37-B via a nucleophilic addition process. Then, the nucleophilic attack of $\mathbf{3 7 - B}$ by protic nucleophiles results in the intermediate $37-\mathrm{C}$. The protonation of $37-\mathrm{C}$ delivers the final product and regenerate gold(I)-catalyst. 


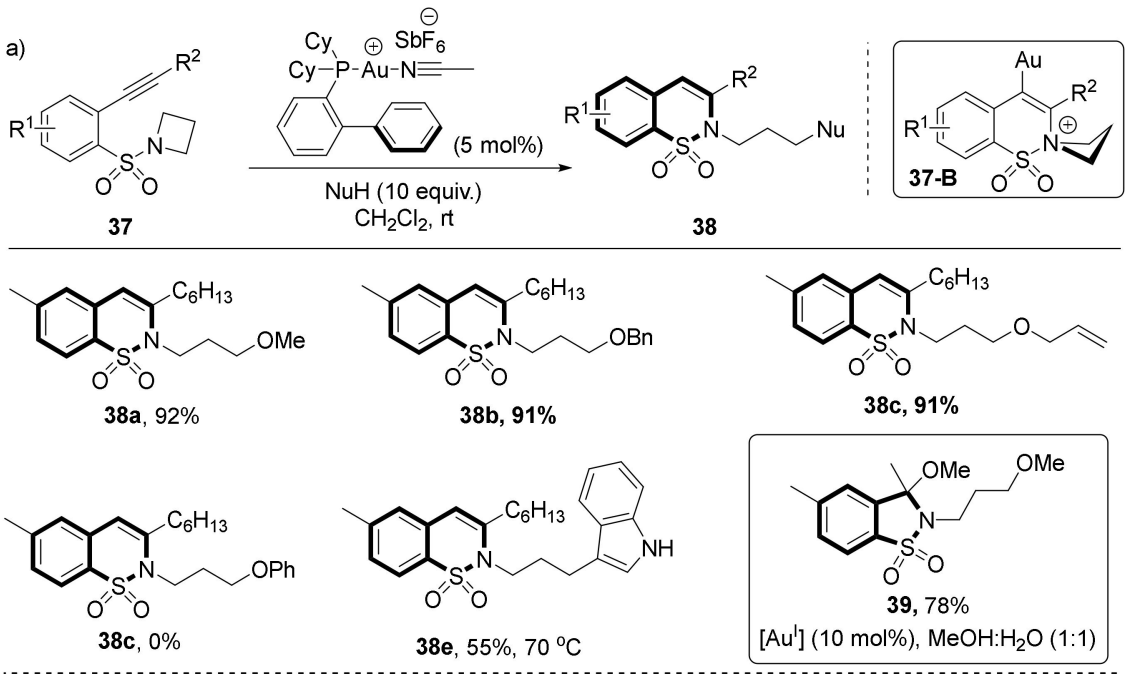

b)
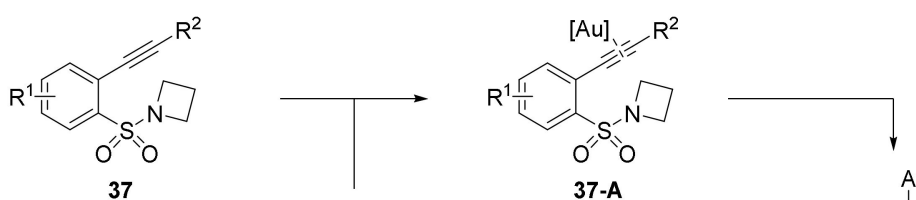

37

37-A<smiles>[R]C1=Cc2cc[R1]cc2S(=O)(=O)N1CCCN</smiles>

$[\mathrm{Au}]^{+}$

Gold catalysis<smiles>[R]C1=C([AlH2])C2=C(C=C[R1]C=C2)S(=O)(=O)N1CCCN</smiles>

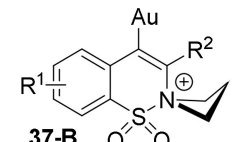

37-B O"

$37-C$

Scheme 14. (a) Synthesis of benzosultams from N-(2-alkynyl)-phenylsulfonyl azetidines; (b) Proposed mechanism.

\section{Visible Light Photocatalytic Synthesis of Benzosultams}

In recent years, visible light-photoredox catalysis has emerged as an ideal tool for the generation of radical species. Taking advantage of the unique and high reactivity of radical intermediates, visible light-induced catalytic synthesis provides new synthetic opportunities to reaction invention and complex molecule construction, which offers good solutions to unlock previously inaccessible reactions [92-108].

Under mild visible light-photocatalytic conditions, in 2016, Wu and Kuang et al. achieved a facile synthesis of benzosultams from 2-ethynylbenzenesulfonamides and Togni's reagent (Scheme 15) [109]. $\operatorname{Ir}(\mathrm{ppy})_{3}$ was demonstrated as the best choice of photocatalyst, while other commonly used catalysts, such as $\mathrm{Ru}(\mathrm{bpy})_{3}\left(\mathrm{PF}_{6}\right)_{2}$ or eosin $\mathrm{Y}$, were ineffective. This reaction displayed a broad substrate scope. For example, 2-ethynylbenzenesulfonamides bearing electron-donating or -withdrawing groups at aromatic ring were smoothly transferred into benzosultam products in good yields with relatively low $E / Z$ selectivity. Importantly, increasing the steric hindrance of the protecting groups on the nitrogen atom could largely improve the E/Z selectivity. When cyclohexyl, tert-butyl, and sec-butyl groups were used, $(E)$-benzosultams could be obtained as the major products.

As depicted in Scheme 16, upon the irradiation of visible light, the ground state of photosensitizer $\operatorname{Ir}(\text { ppy })_{3}$ can be transferred into its excited state ${ }^{*}\left[\operatorname{Ir}(\text { ppy })_{3}\right]$, which undergoes an oxidative quenching by Togni's reagent 41 to generate radical anion intermediate 41-A. Then, the C-I bond homolytic cleavage of intermediate 41-A forms a trifluoromethyl radical. The rapid radical addition of trifluoromethyl radical to 2-ethynylbenzenesulfonamide $\mathbf{4 0}$ would offer the alkenyl radical $\mathbf{4 0 - A}$, followed by a SET oxidation pathway to give alkenyl cation intermediate $40-B$ along with the regeneration of the ground 
state of $\operatorname{Ir}(\mathrm{ppy})_{3}$, thus completing the photocatalytic cycle. Finally, under basic conditions, there is the intramolecular nucleophilic addition of intermediate 40-B to produce the benzosultam product.

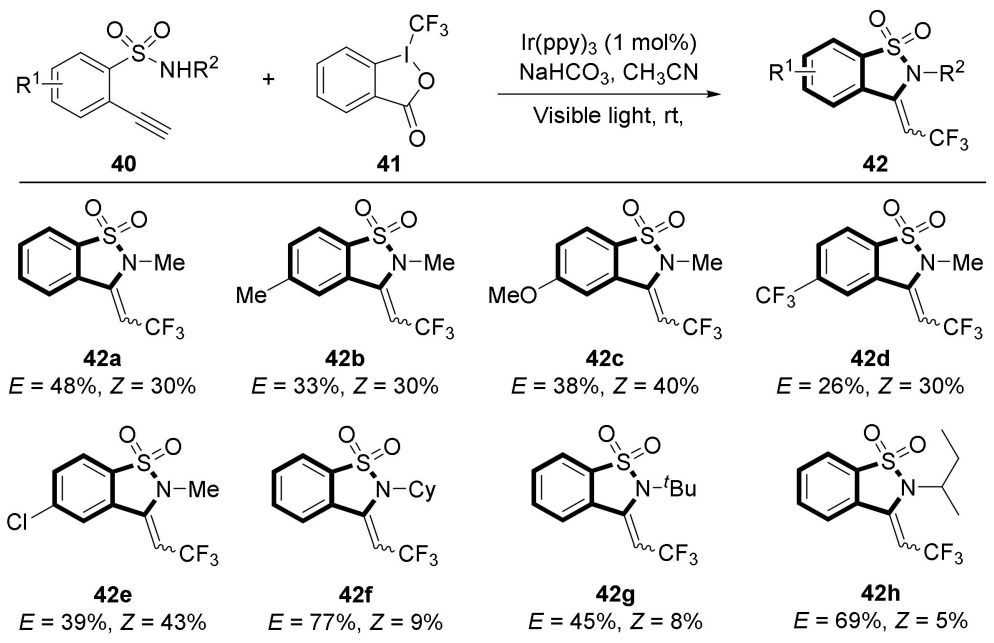

Scheme 15. Photocatalyzed trifluoromethylation/cyclization for benzosultams.

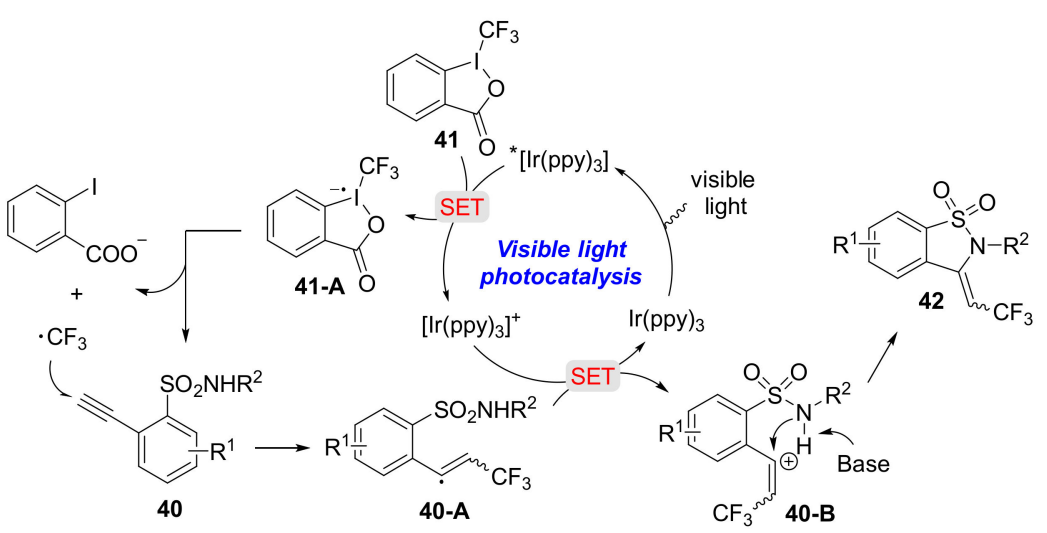

Scheme 16. Proposed mechanism for photocatalytic trifluoromethylation/cyclization.

Shortly afterward, using diazonium salts as a radical source in place of Togni's reagent, Alcaide and Almendros et al. finished the synthesis of 3,4-diaryl-benzosultams with satisfactory yields by cooperative gold and photoredox catalysis (Scheme 17) [110]. This dual catalytic system can be applied for the divergent construction of other heterocyclic cores, such as benzothiophenes, isocoumarins and $3 \mathrm{H}$-indoles, which highlighted the utility of this methodology.

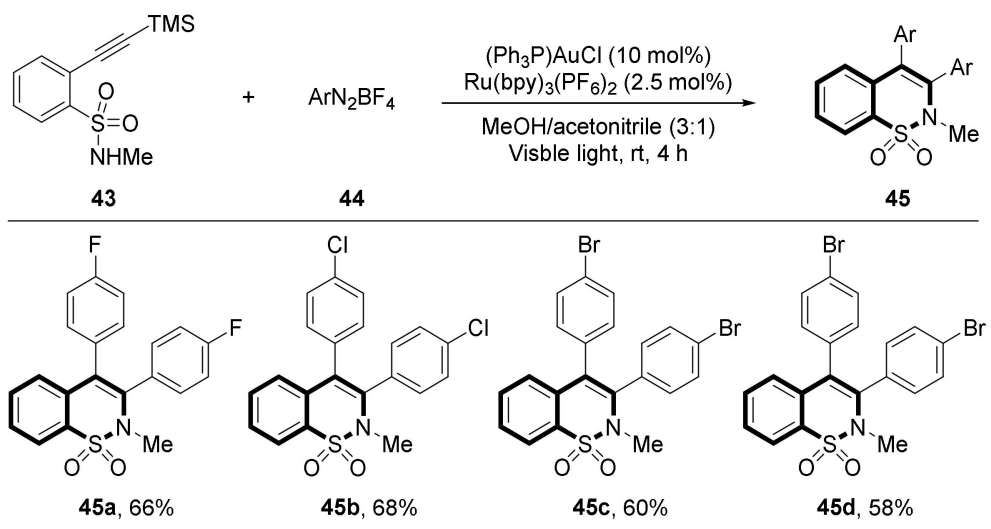

Scheme 17. Dual photoredox and gold catalysis for benzosultams synthesis. 
The synthesis of benzosultams under metal-free conditions is undoubtedly appealing in organic and medicinal chemistry. Very recently, Zeng and co-workers developed a photo/disulfide-induced carbooxygenation of $\mathrm{N}$-arylsulfonylamido alkynes by employing Eosin $\mathrm{Y}$ as the organic photocatalyst and molecular $\mathrm{O}_{2}$ as a green oxygen source, offering an efficient way to access benzosultams (Scheme 17) [111]. A range of functional groups, such as trifluoromethyl, chloro, and bromo, were compatible with the reactions to give variously substituted benzosultams in acceptable yields. The key to its success was the addition of PhSSPh for the in situ generation a thiyl radical. The authors found that the reaction could occur to give a $48 \%$ yield of product in the absence of Eosin $Y$ and no reaction was observed without PhSSPh. As outlined in Scheme 18, the reaction starts with the formation of a thiyl radical through visible light-induced homolysis of PhSSPh. Meanwhile, upon the irradiation of $30 \mathrm{~W}$ blue LEDs, the reductive quenching of photoexcited Eosin $\mathrm{Y}^{*}\left(\mathrm{EY}^{*}\right)$ by PhSSPh provides another pathway to generate the thiyl radical. The subsequent radical addition of thiyl radical to the alkyne group results in a $\mathrm{C}$-Centered radical 46-A, followed by a 5-exo-cylization, SET oxidation, 1,2-migration, and aromatization cascade to give intermediate 46-F. In addition, radical 46-A can also undergo a sequential 6-endo-cylization, SET oxidation, and aromatization process to deliver the same radical intermediate 46-F. Then, thiyl radical abstracts a H-atom from 46-F to form radical 46-G, followed by an isomerization process to generate $46-\mathrm{H}$. The resultant $46-\mathrm{H}$ further reacts with molecular $\mathrm{O}_{2}$ to give the final product 48 .

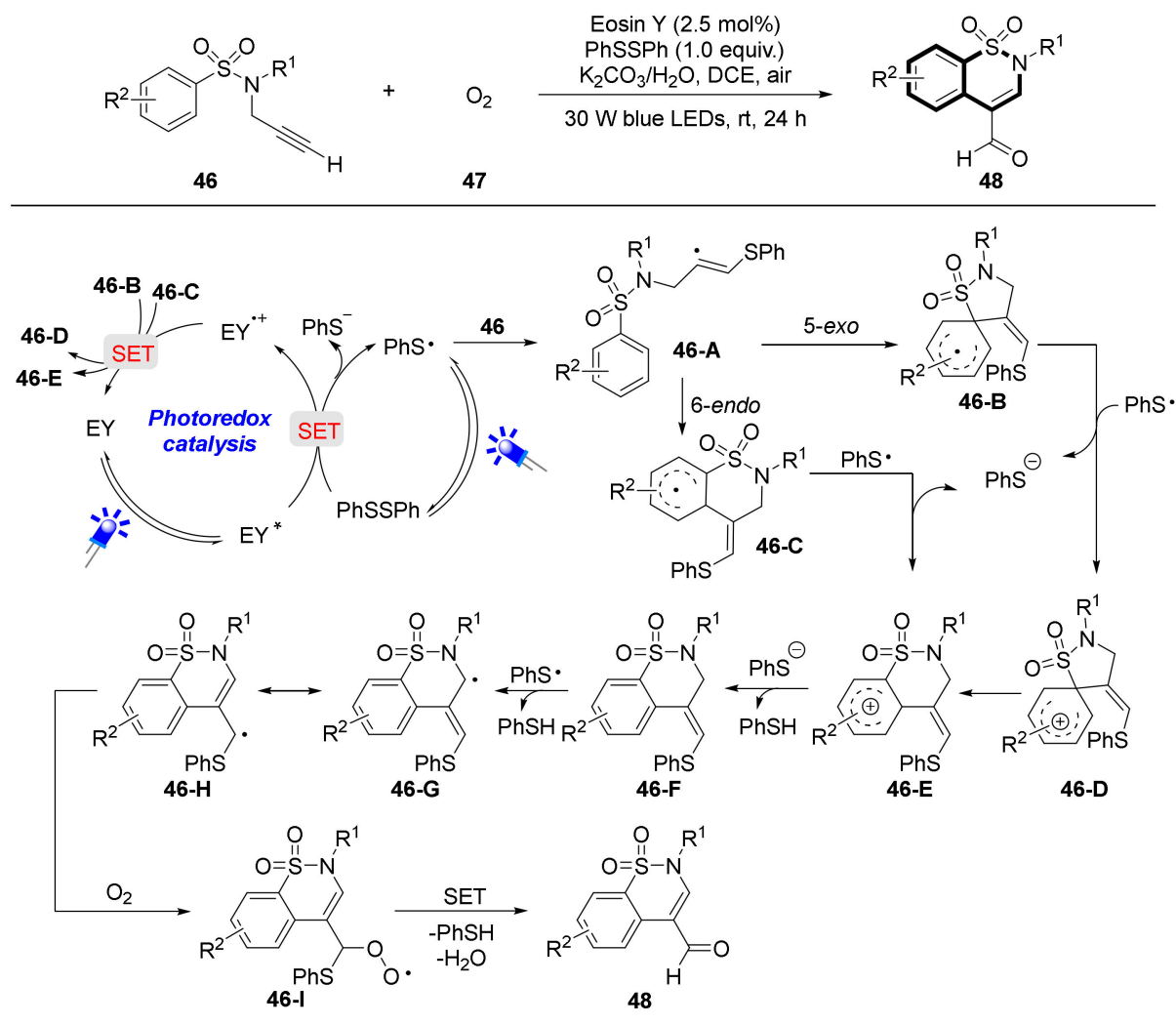

Scheme 18. Photo/disulfide-induced carbooxygenation of N-arylsulfonylamido alkynes.

In addition, Xiao and Chen et al. developed a dual catalytic system for the efficient preparation of dihydropyrazole-fused benzosultams from $\beta, \gamma$-unsaturated hydrazones by the merging of visible light photoredox catalysis and cobalt catalysis (Scheme 19) [112]. In the absence of cobalt catalyst, this visible light-induced N-radical reaction proceeded smoothly, delivering the unsaturated compound 51, which is unstable and can be slowly oxidized to the aromatic product 50 under air conditions. The addition of a suitable cobalt catalyst plays an important role to facilitate this aromatization process by the generation of $\mathrm{H}_{2}$ as the sole byproduct, avoiding the use of other external oxidants. A series 
of aromatic or aliphatic group-substituted $\beta, \gamma$-unsaturated hydrazones participated in this reaction smoothly, which demonstrated the generality of this cascade reaction.

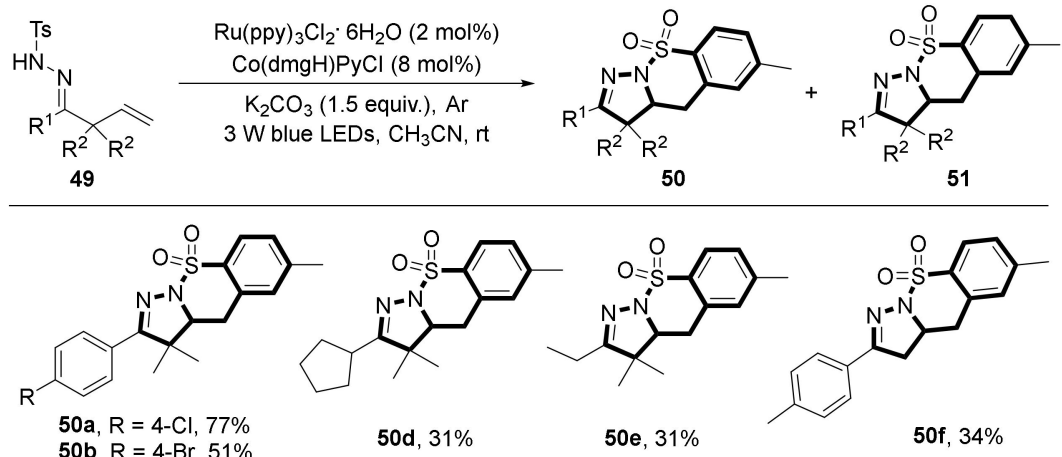

Scheme 19. Dual photoredox and cobalt catalysis for benzosultam synthesis.

Radical-trapping experiments by TEMPO indicated the involvement of a C-based radical, which was believed to be generated from the intramolecular addition of an N-centered radical to $\mathrm{C}=\mathrm{C}$ bonds. The fluorescence quenching studies disclosed that the photoexcited ${ }^{*}\left[\mathrm{Ru}(\mathrm{bpy})_{3}\right]^{2+}$ was efficiently quenched by the nitrogen anion generated from the deprotonation of $\beta, \gamma$-unsaturated hydrazones. Taken together, a visible light-induced N-radical 5-exo cyclization, addition, and aromatization pathway is proposed. As depicted in Scheme 20, the initial deprotonation of hydrazone generates nitrogen anion intermediate 49-A under the basic conditions. Meanwhile, upon the irradiation of $3 \mathrm{~W}$ blue LEDs, the photoexcitation of the ground state of photocatalyst $\left[\mathrm{Ru}(\mathrm{bpy})_{3}\right]^{2+}$ generates ${ }^{*} \mathrm{Ru}^{2+}$ species, which is quickly quenched by $\mathrm{N}$-anion 49-A to give $\mathrm{N}$-centered radical 49-B, together with the formation of reduced $\mathrm{Ru}^{1+}$ catalyst. Then, radical 49-B undergoes an intramolecular cyclization and addition cascade to give radical species $49-\mathrm{D}$. The $\mathrm{Co}(\mathrm{III})$-catalyst can regenerate the ground state of $\left[\mathrm{Ru}(\mathrm{bpy})_{3}\right]^{2+}$ through a SET oxidation, closing the photocatalytic cycle along with generating Co(II)-catalyst. The oxidation of intermediate 49-D by $\mathrm{Co}(\mathrm{II})$-catalyst results in cationic intermediate 49 -E and $\mathrm{Co}(\mathrm{I})$-catalyst. Under the basic conditions, the deprotonation of the resultant 49-E produces the final product. The combination of $\mathrm{Co}(\mathrm{I})$-catalyst with a proton gives rise to $\mathrm{Co}(\mathrm{III})-\mathrm{H}$ intermediate, which may couple with another proton to release $\mathrm{H}_{2}$ and regeneration of the $\mathrm{Co}(\mathrm{III})$ catalyst, thus completing the cobalt catalytic cycle. The reduction of radical 49-D by $\left[\mathrm{Ru}(\mathrm{bpy})_{3}\right]^{1+}$ delivers intermediate $49-\mathrm{F}$, followed by a protonation process to give the unsaturated compound $\mathbf{5 1 .}$

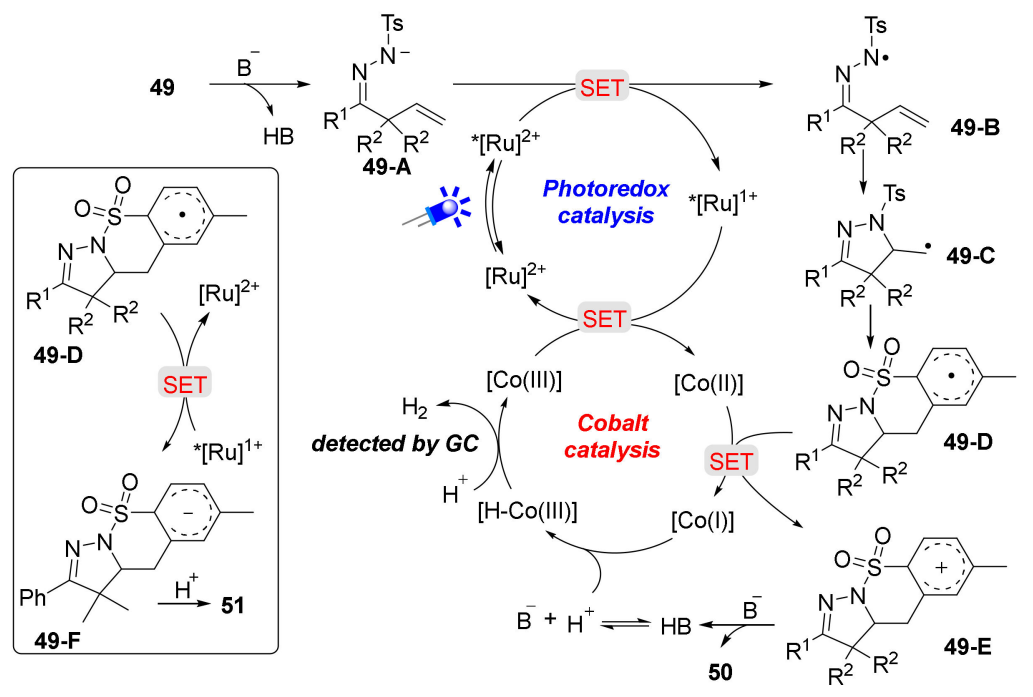

Scheme 20. Proposed mechanism for the N-centered radical cascade reaction. 


\section{Conclusions}

Benzosultams, a subclass of bicyclic sulfonamides, are privileged skeletons in various biologically active compounds and chiral catalysts. The development of efficient methods for their synthesis plays a vital role in new reaction invention and drug discovery. The purpose of this review was to summarize the recent achievements in the field of catalytic synthesis of structurally diverse benzosultams from 2017 to August 2020, with an emphasis on catalytic models, substrate scopes, and reaction mechanisms. Accordingly, transition metal-catalyzed strategies for benzosultam synthesis, including $\mathrm{C}\left(\mathrm{sp}^{2}\right)-\mathrm{H}$ functionalization, $\mathrm{C}\left(\mathrm{sp}^{3}\right)-\mathrm{H}$ amination, and alkyne hydroamination were highlighted in Section 2. Visible light-induced catalytic strategies, which are rarely covered in previous reviews, were discussed in detail in Section 3. These reactions provide convenient and alternative platforms for the construction of benzosultams.

Despite these impressive advances, there are still some challenges in this field as follows: (1) Catalytic asymmetric synthesis of benzosultams; and (2) large-scale synthesis. We believe that the further exploration of novel dual catalytic systems by rational combination of transition metal or organocatalysis with photoredox catalysis may provide good solutions to the mentioned problems. The continuous flow processing can greatly improve reaction efficiency, thus facilitating large-scale synthesis. We hope this review will inspire more interest in the development of efficient catalytic strategies for benzosultam synthesis.

Author Contributions: Writing—original draft preparation, Q.-Q.Z.; writing—review and editing, X.-Q.H. All authors have read and agreed to the published version of the manuscript.

Funding: This research was funded by the National Natural Science Foundation of China (21901258) and the South-Central University of Nationalities (YZZ19003).

Conflicts of Interest: The authors declare no conflict of interest.

\section{References}

1. Domagk, G. Ein Beitrag zur Chemotherapie der bakteriellen Infektionen. Dtsch. Med. Wochenschr. 1935, 61, 250-253. [CrossRef]

2. Hanessian, S.; Sailes, H.; Therrien, E. Synthesis of Functionally Diverse Bicyclic Sulfonamides as Constrained Proline Analogues and Application to the Design of Potential Thrombin Inhibitors. Tetrahedron 2003, 59, 7047-7056. [CrossRef]

3. Tanimukai, H.; Inui, M.; Harigushi, S.; Kaneko, Z. Antiepileptic Property of Inhibitors of Carbonic Anhydrase. J. Biochem. Pharm. 1965, 14, 961-970.

4. Wells, G.J.; Tao, M.; Josef, K.A.; Bihovsky, R. 1,2-Benzothiazine 1,1-Dioxide $\mathrm{P}_{2}$-P $\mathrm{P}_{3}$ Peptide Mimetic Aldehyde Calpain I Inhibitors. J. Med. Chem. 2001, 44, 3488-3503. [CrossRef]

5. Brzozowski, Z.; Saczewski, F.; Neamati, N. Bioorg. Synthesis and Anti-HIV-1 Activity of a Novel Series of 1,4,2-benzodithiazine-dioxides. Med. Chem. Lett. 2006, 16, 5298-5302. [CrossRef] [PubMed]

6. Xie, Y.; Gong, G.; Liu, Y.; Deng, S.; Rinderspacher, A.; Branden, L.; Landry, D.W. Convenient Preparation of N-8-quinolinyl Benzenesultams as Novel NF-KB Inhibitors. Tetrahedron Lett. 2008, 49, 2320-2323. [CrossRef]

7. Ahmad, N.; Zia-ur-Rehman, M.; Siddiqui, H.L.; Ullah, M.F.; Parvez, M. Microwave Assisted Synthesis and Structure-Activity Relationship of 4-Hydroxy- $\mathrm{N}^{\prime}$-[1-phenylethylidene]-2H/2-methyl-1,2-benzothiazine-3-carbohydrazide 1,1-dioxides as Anti-Microbial Agents. Eur. J. Org. Chem. 2011, 46, 2368-2377.

8. Ivanova, D.; Deneva, V.; Nedeltcheva, D.; Kamounah, F.S.; Gergov, G.; Hansen, P.E.; Kawauchi, S.; Antonov, L. Tautomeric Transformations of Piroxicam in Solution: A Combined Experimental and Theoretical Study. RSC Adv. 2015, 5, 31852-31860. [CrossRef]

9. Li, X.; Dong, Y.; Qu, F.; Liu, G. Synthesis of Benzofused Five-Ring Sultams via Rh-Catalyzed C-H Olefination Directed by an N-Ac-Substituted Sulfonamide Group. J. Org. Chem. 2015, 80, 790-798. [CrossRef]

10. Azevedo, C.M.; Watterson, K.R.; Wargent, E.T.; Hansen, S.V.; Hudson, B.D.; Kepczynska, M.A.; Dunlop, J.; Shimpukade, B.; Christiansen, E.; Milligan, G.; et al. Non-Acidic Free Fatty Acid Receptor 4 Agonists with Antidiabetic Activity. J. Med. Chem. 2016, 59, 8868-8878. [CrossRef] 
11. Lei, K.; Hua, X.W.; Tao, Y.Y.; Liu, Y.; Liu, N.; Ma, Y.; Li, Y.H.; Xu, X.H.; Kong, C.H. Discovery of (2-Benzoylethen-1-ol)-Containing 1,2-Benzothiazine Derivatives as Novel 4-Hydroxyphenylpyruvate Dioxygenase (HPPD) Inhibiting-Based Herbicide Lead Compounds. Bioorg. Med. Chem. 2016, 24, 92-103. [CrossRef] [PubMed]

12. Mondal, S.; Mukherjee, S.; Malakar, S.; Debnath, S.; Roy, P.; Sinha Babu, S.P. Studying the Biological Activities and Molecular Docking of Some Novel Benzosultams and Benzosultones. Curr. Bioact. Comp. 2017, 13, 347-355. [CrossRef]

13. Ahn, K.H.; Kim, S.K.; Ham, C. The Evaluation of Chiral Benzosultams as Auxiliaries in Asymmetric Azidation Reaction. Tetrahedron Lett. 1998, 39, 6321-6322. [CrossRef]

14. Zhao, H.-W.; Chen, X.-Q.; Pang, H.-L.; Tian, T.; Li, B.; Song, X.-Q.; Meng, W.; Yang, Z.; Zhao, Y.-D.; Liu, Y.-Y. Diastereoselective Synthesis of Highly Functionalized Polycyclic Benzosultams via Tandem Cyclisations of Cyclic N-Sulfonylimines with in Situ Generated Huisgen 1,4-Dipoles. RSC Adv. 2016, 6, 61732-61739. [CrossRef]

15. Laha, J.K.; Jethava, K.P. Access to Imidazolidine-Fused Sulfamidates and Sulfamides Bearing a Quaternary Center via 1,3-Dipolar Cycloaddition of Nonstabilized Azomethine Ylides. J. Org. Chem. 2017, 82, 3597-3604. [CrossRef]

16. Nishimura, T.; Noishiki, A.; Tsui, G.C.; Hayashi, T. Asymmetric Synthesis of (Triaryl)methylamines by Rhodium-Catalyzed Addition of Arylboroxines to Cyclic N-Sulfonyl Ketimines. J. Am. Chem. Soc. 2012, 134, 5056-5059. [CrossRef]

17. Wang, H.; Jiang, T.; Xu, M.H. Simple Branched Sulfur-Olefins as Chiral Ligands for Rh-Catalyzed Asymmetric Arylation of Cyclic Ketimines: Highly Enantioselective Construction of Tetrasubstituted Carbon Stereocenters. J. Am. Chem. Soc. 2013, 135, 971-974. [CrossRef]

18. Jiang, T.; Wang, Z.; Xu, M.H. Rhodium-Catalyzed Asymmetric Arylation of Cyclic N-Sulfonyl Aryl Alkyl Ketimines: Efficient Access to Highly Enantioenriched Alpha-Tertiary Amines. Org. Lett. 2015, 17, 528-531. [CrossRef]

19. Qiao, B.; Huang, Y.J.; Nie, J.; Ma, J.A. Highly Regio-, Diastereo-, and Enantioselective Mannich Reaction of Allylic Ketones and Cyclic Ketimines: Access to Chiral Benzosultam. Org. Lett. 2015, 17, 4608-4611. [CrossRef]

20. Yu, J.-S.; Zhou, J. Organocatalytic Enantioselective Mukaiyama-Mannich Reaction of Fluorinated Enol Silyl Ethers and Cyclic N-Sulfonyl Ketimines. Org. Chem. Front. 2016, 3, 298-303. [CrossRef]

21. Hou, L.; Kang, T.; Yang, L.; Cao, W.; Feng, X. Enantioselective Imino-Ene Reaction of N-Sulfonyl Ketimines with Silyl Enol Ethers: Access to Chiral Benzosultams. Org. Lett. 2020, 22, 1390-1395. [CrossRef] [PubMed]

22. Liu, H.; Li, J.; Xiong, M.; Jiang, J.; Wang, J. Cp*Co ${ }^{\text {III }-C a t a l y z e d ~ C-H ~ A l k e n y l a t i o n / A n n u l a t i o n ~ t o ~ A f f o r d ~ S p i r o ~}$ Indenyl Benzosultam. J. Org. Chem. 2016, 81, 6093-6099. [CrossRef] [PubMed]

23. Reddy, K.N.; Rao, M.V.K.; Sridhar, B.; Reddy, B.V.S. Pd ${ }^{\mathrm{II}}$-Catalyzed Spiroannulation of Cyclic N-Sulfonyl Ketimines with Aryl Iodides through C-H Bond Activation. Eur. J. Org. Chem. 2017, 2017, 4085-4090. [CrossRef]

24. Nagarjuna, R.K.; Subhadra, U.; Sridhar, B.; Subba, R.B.V. Ru(II)-Catalyzed Spirocyclization of Aryl N-Sulfonyl Ketimines with Aryl Isocyanates Through an Aromatic C-H bond activation. Org. Biomol. Chem. 2018, 16, 2522-2526.

25. Li, Q.; Yuan, X.; Li, B.; Wang, B. The Regioselective Annulation of Alkylidenecyclopropanes by Rh(III)-Catalyzed C-H/C-C Activation to Access Spirocyclic Benzosultams. Chem. Commun. 2020, 56, 1835-1838. [CrossRef] [PubMed]

26. Enders, D.; Seppelt, M. Catalytic Enantioselective Synthesis of 3-Substituted Benzosultams via Corey-Bakshi-Shibata Reduction of Cyclic N-Sulfonylimines. Synlett 2011, 2011, 402-404. [CrossRef]

27. Pan, J.; Wu, J.H.; Zhang, H.; Ren, X.; Tan, J.P.; Zhu, L.; Zhang, H.S.; Jiang, C.; Wang, T. Highly Enantioselective Synthesis of Fused Tri- and Tetrasubstituted Aziridines: Aza-Darzens Reaction of Cyclic Imines with

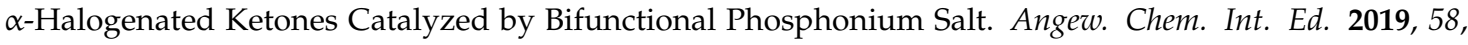
7425-7430. [CrossRef] [PubMed]

28. Li, Y.; Ding, Q.; Qiu, G.; Wu, J. Synthesis of Benzosultams via an Intramolecular Sp ${ }^{2}$ C-H bond Amination Reaction of o-Arylbenzenesulfonamides under Metal-Free Conditions. Org. Biomol. Chem. 2014, 12, 149-155. [CrossRef] 
29. Ghandi, M.; Kia, M.A.; Sadeghzadegh, M.; Bozcheloei, A.H.; Kubicki, M. Diastereoselective Synthesis of Novel Pyrrolidine or Pyrrolizine-Fused Benzo- $\delta$-Sultams via 1,3-Dipolar Cycloadditions. J. Heterocycl. Chem. 2015, 52, 1646-1653. [CrossRef]

30. Grosheva, D.S.; Rassadin, V.A.; Sokolov, V.V. A Route to Benzo-Annelated $\delta$-Sultams through Michael Cyclization. Eur. J. Org. Chem. 2015, 2015, 1355-1363. [CrossRef]

31. Wojciechowski, K.; Makosza, M. Synthesis of Benzosultams via Intramolecular Vicarious Nucleophilic Substitution of Hydrogen. Synthesis 1992, 1992, 571-576. [CrossRef]

32. Wu, C. Novel Synthesis of N-Methyl-1,2-benzosultams, an Unsuspected Demethylative Intramolecular Cyclization Reaction. J. Org. Chem. 1998, 63, 2348-2350. [CrossRef]

33. Ahn, K.H.; Baek, H.H.; Lee, S.J.; Cho, C.W. Synthesis of Chiral Benzosultams: 3-Functionalized 1,2-Benzisothiazoline 1,1-dioxides. J. Org. Chem. 2000, 65, 7690-7696. [CrossRef]

34. Philippe, D.; Dodd, R.H. Intramolecular Bromine-Catalyzed Aziridination: A New Direct Access to Cyclic Sulfonamides. Tetrahedron Lett. 2001, 42, 1037-1040.

35. Liu, Z.; Shibata, N.; Takeuchi, Y. Facile Synthesis of Disubstituted and Spiro Five-Membered Benzosultams Mediated by TMSCl-NaI-MeCN Reagent. J. Chem. SocPerkin Trans. 2002, 1, 302-303. [CrossRef]

36. Fang, F.; Wang, R.; Liu, Z.-P.; Ji, A.-G. Novel Method for the Synthesis of 3-Monosubstituted Six-Membered Benzosultams. Heterocycles 2007, 71, 2377-2388.

37. Sun, H.M.; Liu, Z.P.; Tang, L.Q. Synthesis of Novel Chiral Fluorinating Agents, (+)- and (-)-N-Fluoro-3-Methyl-3-(4-Methylphenyl)-2H-Benzo[e][1,2]Thiazine-1,1,4-Triones. Chin. Chem. Lett. 2008, 19, 907-910. [CrossRef]

38. Liu, Z.P.; Dong, Y.H.; Ni, Q.W.; Ma, S.T. Iodotrimethylsilane and Catalytic Iodine Promoted Cyclization for the Facile Synthesis of 3-Monoarylated Five-Membered Benzosultams. Heterocycles 2010, 81, 637-648. [CrossRef]

39. Lorion, M.; Agouridas, V.; Couture, A.; Deniau, E.; Grandclaudon, P. Cyclic Sulfamidates as Vehicles for the Synthesis of Poly- and Diversely Substituted Benzosultams via Unusual $\mathrm{S}(\mathrm{O})_{2}-\mathrm{O}$ Bond Cleavage. Org. Lett. 2010, 12, 1356-1359. [CrossRef]

40. Majumdar, K.C.; Mondal, S. Recent Developments in the Synthesis of Fused Sultams. Chem. Rev. 2011, 111, 7749-7773. [CrossRef]

41. Debnath, S.; Mondal, S. Sultams: Recent Syntheses and Applications. Eur. J. Org. Chem. 2018, 2018, $933-956$. [CrossRef]

42. Grygorenko, O.O.; Vashchenko, B.V.; Blahun, O.P.; Zhersh, S. Saturated Bicyclic Sultams. Eur. J. Org. Chem. 2020. [CrossRef]

43. Colby, D.A.; Bergman, R.G.; Ellman, J.A. Rhodium-Catalyzed C-C Bond Formation via Heteroatom-Directed C-H Bond Activation. Chem. Rev. 2010, 110, 624-655. [CrossRef] [PubMed]

44. Lyons, T.W.; Sanford, M.S. Palladium-Catalyzed Ligand-Directed C-H Functionalization Reactions. Chem. Rev. 2010, 110, 1147-1169. [CrossRef] [PubMed]

45. Arockiam, P.B.; Bruneau, C.; Dixneuf, P.H. Ruthenium(II)-Catalyzed C-H Bond Activation and Functionalization. Chem. Rev. 2012, 112, 5879-5918. [CrossRef]

46. Kim, D.S.; Park, W.J.; Jun, C.H. Metal-Organic Cooperative Catalysis in C-H and C-C Bond Activation. Chem. Rev. 2017, 117, 8977-9015. [CrossRef]

47. Labinger, J.A. Platinum-Catalyzed C-H Functionalization. Chem. Rev. 2017, 117, 8483-8496. [CrossRef]

48. Shang, R.; Ilies, L.; Nakamura, E. Iron-Catalyzed C-H Bond Activation. Chem. Rev. 2017, 117, $9086-9139$. [CrossRef]

49. Gandeepan, P.; Müller, T.; Zell, D.; Cera, G.; Warratz, S.; Ackermann, L. 3d Transition Metals for C-H Activation. Chem. Rev. 2018, 119, 2192-2452. [CrossRef]

50. Yamagishi, M.; Nishigai, K.; Ishii, A.; Hata, T.; Urabe, H. Facile Preparation of Indoles and 1,2-Benzothiazine 1,1-dioxides: Nucleophilic Addition of Sulfonamides to Bromoacetylenes and Subsequent Palladium-Catalyzed Cyclization. Angew. Chem. Int. Ed. 2012, 51, 6471-6474. [CrossRef]

51. Mondal, S.; Debnath, S.; Pal, S.; Das, A. Synthesis of Uracil-, Coumarin- and Quinolone-Fused Benzosultams and Benzosultones. Synthesis 2015, 47, 3423-3433. [CrossRef]

52. Laha, J.K.; Jethava, K.P.; Dayal, N. Palladium-Catalyzed Intramolecular Oxidative Coupling Involving Double C( $\left.\mathrm{sp}^{2}\right)-\mathrm{H}$ Bonds for the Synthesis of Annulated Biaryl Sultams. J. Org. Chem. 2014, 79, 8010-8019. [CrossRef] [PubMed] 
53. Laha, J.K.; Dayal, N.; Jethava, K.P.; Prajapati, D.V. Access to Biaryl Sulfonamides by Palladium-Catalyzed Intramolecular Oxidative Coupling and Subsequent Nucleophilic Ring Opening of Heterobiaryl Sultams with Amines. Org. Lett. 2015, 17, 1296-1299. [CrossRef]

54. Laha, J.K.; Bhimpuria, R.A.; Kumar, A.M. Post-Synthetic Diversification of Pyrrole-Fused Benzosultams via Trans-Sulfonylations and Reactions on the Periphery of Pyrrole. Org. Chem. Front. 2017, 4, 2170-2174. [CrossRef]

55. Laha, J.K.; Bhimpuria, R.A.; Hunjan, M.K. Intramolecular Oxidative Arylations in 7-Azaindoles and Pyrroles: Revamping the Synthesis of Fused N-Heterocycle Tethered Fluorenes. Eur. Chem. J. 2017, 23, 2044-2050. [CrossRef] [PubMed]

56. Tang, J.; Chen, H.; He, Y.; Sheng, W.; Bai, Q.; Wang, H. Peptide-Guided Functionalization and Macrocyclization of Bioactive Peptidosulfonamides by Pd(II)-Catalyzed Late-Stage C-H Activation. Nat. Commun. 2018, 9 , 3383. [CrossRef]

57. Mas-Moruno, C.; Rechenmacher, F.; Kessler, H. Cilengitide: The First Anti-angiogenic Small Molecule Drug Candidate Design, Synthesis and Clinical Evaluation. Anticancer Agents Med. Chem. 2010, 10, 753-768. [CrossRef]

58. Pham, M.V.; Ye, B.; Cramer, N. Access to Sultams by Rhodium(III)-Catalyzed Directed C-H Activation. Angew. Chem. Int. Ed. 2012, 51, 10610-10614. [CrossRef]

59. Xie, W.; Yang, J.; Wang, B.; Li, B. Regioselective Ortho Olefination of Aryl Sulfonamide via Rhodium-Catalyzed Direct C-H Bond Activation. J. Org. Chem. 2014, 79, 8278-8287. [CrossRef]

60. Ran, Y.; Yang, Y.; You, H.; You, J. $\mathrm{RhCl}_{3}$-Catalyzed Oxidative C-H/C-H Cross-Coupling of (Hetero)aromatic Sulfonamides with (Hetero)arenes. ACS Catal. 2018, 8, 1796-1801. [CrossRef]

61. Hou, H.; Zhao, Y.; Pu, S.; Chen, J. Rhodium-Catalyzed Direct C-H Bond Alkynylation of Aryl Sulfonamides with Bromoalkynes. Org. Biomol. Chem. 2019, 17, 2948-2953. [CrossRef] [PubMed]

62. Li, L.; Gao, H.; Sun, M.; Zhou, Z.; Yi, W. Experimental and Computational Studies on $\mathrm{Cp}^{*}(\mathrm{Cy}) \mathrm{Rh}(\mathrm{III}) / \mathrm{KOPiv}-C a t a l y z e d$ Intramolecular Dehydrogenative Cross-Couplings for Building Eight-Membered Sultam/Lactam Frameworks. Org. Lett. 2020, 22, 5473-5478. [CrossRef] [PubMed]

63. Kalsi, D.; Sundararaju, B. Cobalt Catalyzed C-H and N-H Bond Annulation of Sulfonamide with Terminal and Internal Alkynes. Org. Lett. 2015, 17, 6118-6121. [CrossRef] [PubMed]

64. Thrimurtulu, N.; Nallagonda, R.; Volla, C.M. Cobalt-Catalyzed Aryl C-H Activation and Highly Regioselective Intermolecular Annulation of Sulfonamides with Allenes. Chem. Commun. 2017, 53, 1872-1875. [CrossRef]

65. Chrostowska, A.; Gracian, F.; Sotiropoulos, J.-M.; Pfister-Guillouzo, G.; Wojciechowski, K. UV Photoelectron Spectroscopy Studies of the Products of Thermal Extrusion of Sulfur Dioxide from Benzosultams. Eur. J. Org. Chem. 2000, 2000, 313-318. [CrossRef]

66. Bunnett, J.F.; Kato, T.; Flynn, R.R.; Skorcz, J.A. Studies of Ring Closure via Aryne Intermediates. J. Org. Chem. 1963, 28, 1-6. [CrossRef]

67. Wojciechowski, K. Synthesis of Nitrobenzophenones from Nitro- $\alpha$-Sulfonyldiphenylmethane Derivatives. Synth. Commun. 1997, 27, 135-144. [CrossRef]

68. Moutrille, C.; Zard, S.Z. A New Approach for the ortho-Substitution of Anilines and for the Synthesis of Indolines. Tetrahedron Lett. 2004, 45, 4631-4634. [CrossRef]

69. Yang, Z.; Xu, J. Synthesis of Benzo-Gamma-Sultams via the Rh-Catalyzed Aromatic C-H Functionalization of Diazosulfonamides. Chem. Commun. 2014, 50, 3616-3618. [CrossRef]

70. Huang, P.; Yang, Z.; Xu, J. Specific Intramolecular Aromatic C-H Insertion of Diazosulfonamides. Tetrahedron 2017, 73, 3255-3265. [CrossRef]

71. He, J.; Wasa, M.; Chan, K.S.L.; Shao, Q.; Yu, J.Q. Palladium-Catalyzed Transformations of Alkyl C-H Bonds. Chem. Rev. 2017, 117, 8754-8786. [CrossRef]

72. Ruppel, J.V.; Kamble, R.M.; Zhang, X.P. Cobalt-Catalyzed Intramolecular C-H Amination with Arylsulfonyl Azides. Org. Lett. 2007, 9, 4889-4892. [CrossRef] [PubMed]

73. Lu, H.; Jiang, H.; Wojtas, L.; Zhang, X.P. Selective Intramolecular C-H Amination through the Metalloradical Activation of Azides: Synthesis of 1,3-Diamines under Neutral and Nonoxidative Conditions. Angew. Chem. Int. Ed. 2010, 49, 10192-10196. [CrossRef] [PubMed] 
74. Hu, Y.; Lang, K.; Li, C.; Gill, J.B.; Kim, I.; Lu, H.; Fields, K.B.; Marshall, M.; Cheng, Q.; Cui, X.; et al. Enantioselective Radical Construction of 5-Membered Cyclic Sulfonamides by Metalloradical C-H Amination. J. Am. Chem. Soc. 2019, 141, 18160-18169. [CrossRef] [PubMed]

75. Podust, L.M.; Sherman, D.H. Diversity of P450 Enzymes in the Biosynthesis of Natural Products. Nat. Prod. Rep. 2012, 29, 1251-1266. [CrossRef] [PubMed]

76. Whitehouse, C.J.; Bell, S.G.; Wong, L.L. P450BM3 (CYP102A1): Connecting the Dots. Chem. Soc. Rev. 2012, 41, 1218-1260. [CrossRef]

77. Bordeaux, M.; Galarneau, A.; Fajula, F.; Drone, J. A regioselective biocatalyst for alkane activation under mild conditions. Angew. Chem. Int. Ed. 2011, 50, 2075-2079. [CrossRef]

78. McIntosh, J.A.; Coelho, P.S.; Farwell, C.C.; Wang, Z.J.; Lewis, J.C.; Brown, T.R.; Arnold, F.H. Enantioselective Intramolecular C-H Amination Catalyzed by Engineered Cytochrome P450 Enzymes in Vitro and in Vivo. Angew. Chem. Int. Ed. 2013, 52, 9309. [CrossRef]

79. Hyster, T.K.; Farwell, C.C.; Buller, A.R.; McIntosh, J.A.; Arnold, F.H. Enzyme-Controlled Nitrogen-Atom Transfer Enables Regiodivergent C-H Amination. J. Am. Chem. Soc. 2014, 136, 15505-15508. [CrossRef]

80. Bordeaux, M.; Singh, R.; Fasan, R. Intramolecular C(sp $\left.{ }^{3}\right)-H$ Amination of Arylsulfonyl Azides with Engineered and Artificial Myoglobin-Based Catalysts. Bioorg. Med. Chem. 2014, 22, 5697-5704. [CrossRef]

81. Singh, R.; Bordeaux, M.; Fasan, R. P450-Catalyzed Intramolecular sp3 C-H Amination with Arylsulfonyl Azide Substrates. ACS Catal. 2014, 4, 546-552. [CrossRef]

82. Hyster, T.K.; Ward, T.R. Genetic Optimization of Metalloenzymes: Enhancing Enzymes for Non-Natural Reactions. Angew. Chem. Int. Ed. 2016, 55, 7344-7357. [CrossRef] [PubMed]

83. Dydio, P.; Key, H.M.; Hayashi, H.; Clark, D.S.; Hartwig, J.F. Chemoselective, Enzymatic C-H Bond Amination Catalyzed by a Cytochrome P450 Containing an Ir(Me)-PIX Cofactor. J. Am. Chem. Soc. 2017, 139, 1750-1753. [CrossRef]

84. Scamp, R.J.; Scheffer, B.; Schomaker, J.M. Regioselective Differentiation of Vicinal Methylene C-H bonds Enabled by Silver-Catalysed Nitrene Transfer. Chem. Commun. 2019, 55, 7362-7365. [CrossRef] [PubMed]

85. Barange, D.K.; Nishad, T.C.; Swamy, N.K.; Bandameedi, V.; Kumar, D.; Sreekanth, B.R.; Vyas, K.; Pal, M. A Remarkable Accelerating Effect of Ag-Salt on Intramolecular Cyclization of o-(1-Alkynyl)Benzenesulfonamides. J. Org. Chem. 2007, 72, 8547-8550. [CrossRef] [PubMed]

86. Rambabu, D.; Murthy, P.V.N.S.; Prasad, K.R.S.; Kandale, A.; Deora, G.S.; Basaveswara Rao, M.V.; Pal, M. $\mathrm{AgNO}_{3}$ Mediated C-N Bond Forming Reaction: Synthesis of 3-Substituted Benzothiazines as Potential COX Inhibitors. Tetrahedron Lett. 2012, 53, 6577-6583. [CrossRef]

87. Debnath, S.; Mondal, S. One-pot Sonogashira Coupling-Cyclization toward Regioselective Synthesis of Benzosultams. J. Org. Chem. 2015, 80, 3940-3948. [CrossRef]

88. Ha, T.M.; Yao, B.; Wang, Q.; Zhu, J. Sulfonamide and Tertiary Amine as Nucleophiles in Pd(II)-Catalyzed Diamination of Alkynes: Synthesis of Tetracyclic Indolobenzothiazine S,S-Dioxides. Org. Lett. 2015, 17, 5256-5259. [CrossRef]

89. Debnath, S.; Mondal, S. One-Pot Sonogashira Coupling, Hydroamination of Alkyne and Intramolecular C H Arylation Reactions toward the Synthesis of Indole-fused Benzosultams. Tetrahedron Lett. 2018, 59, 2260-2263. [CrossRef]

90. Maheshwar Rao, B.; Yadav, J.S.; Sridhar, B.; Subba Reddy, B.V. Silver(I)-Catalyzed Sequential Hydroamination and Prins Type Cyclization for the Synthesis of Fused Benzo- $\delta$-sultams. Org. Biomol. Chem. 2018, 16, 5163-5166. [CrossRef]

91. Pertschi, R.; Weibel, J.M.; Pale, P.; Blanc, A. Benzosultam Synthesis by Gold(I)-Catalyzed Ammonium Formation/Nucleophilic Substitution. Org. Lett. 2019, 21, 5616-5620. [CrossRef] [PubMed]

92. Zeitler, K. Photoredox Catalysis with Visible Light. Angew. Chem. Int. Ed. 2009, 48, 9785-9789. [CrossRef]

93. Yoon, T.P.; Ischay, M.A.; Du, J. Visible Light Photocatalysis as a Greener Approach to Photochemical Synthesis. Nat. Chem. 2010, 2, 527-532. [CrossRef] [PubMed]

94. Stephenson, C.R.J. Visible Light Photoredox Catalysis: Applications in Organic Synthesis. Chem. Soc. Rev. 2011, 40, 102-113.

95. Xuan, J.; Xiao, W.J. Visible-Light Photoredox Catalysis. Angew. Chem. Int. Ed. 2012, 51, 6828-6838. [CrossRef] [PubMed]

96. Prier, C.K.; Rankic, D.A.; MacMillan, D.W. Visible Light Photoredox Catalysis with Transition Metal Complexes: Applications in Organic Synthesis. Chem. Rev. 2013, 113, 5322-5363. [CrossRef] 
97. Ravelli, D.; Fagnoni, M.; Albini, A. Photoorganocatalysis. What for? Chem. Soc. Rev. 2013, 42, 97-113. [CrossRef]

98. Zou, Y.Q.; Chen, J.R.; Xiao, W.J. Homogeneous Visible-Light Photoredox Catalysis. Angew. Chem. Int. Ed. 2013, 52, 11701-11703. [CrossRef]

99. Hopkinson, M.N.; Sahoo, B.; Li, J.L.; Glorius, F. Dual Catalysis Sees the Light: Combining Photoredox with Organo-, Acid, and Transition-Metal Catalysis. Eur. Chem. J. 2014, 20, 3874-3886. [CrossRef]

100. Schultz, D.M.; Yoon, T.P. Solar Synthesis: Prospects in Visible Light Photocatalysis. Science 2014, $343,985$. [CrossRef]

101. Chen, J.R.; Hu, X.Q.; Lu, L.Q.; Xiao, W.J. Exploration of Visible-Light Photocatalysis in Heterocycle Synthesis and Functionalization: Reaction Design and Beyond. Acc. Chem. Res. 2016, 49, 1911-1923. [CrossRef] [PubMed]

102. Garbarino, S.; Ravelli, D.; Protti, S.; Basso, A. Photoinduced Multicomponent Reactions. Angew. Chem. Int. Ed. 2016, 55, 15476-15484. [CrossRef] [PubMed]

103. Ravelli, D.; Protti, S.; Fagnoni, M. Carbon-Carbon Bond Forming Reactions via Photogenerated Intermediates. Chem. Rev. 2016, 116, 9850-9913. [CrossRef] [PubMed]

104. Romero, N.A.; Nicewicz, D.A. Organic Photoredox Catalysis. Chem. Rev. 2016, 116, 10075-10166. [CrossRef] [PubMed]

105. Twilton, J.; Le, C.; Zhang, P.; Shaw, M.H.; Evans, R.W.; MacMillan, D.W.C. The Merger of Transition Metal and Photocatalysis. Nat. Rev. Chem. 2017, 1, 0052. [CrossRef]

106. Marzo, L.; Pagire, S.K.; Reiser, O.; Konig, B. Visible-Light Photocatalysis: Does It Make Difference in Organic Synthesis? Anfgew. Chem. Int. Ed. 2018, 57, 10034-10072. [CrossRef]

107. Strieth-Kalthoff, F.; James, M.J.; Teders, M.; Pitzer, L.; Glorius, F. Energy Transfer Catalysis Mediated by Visible Light: Principles, Applications, Directions. Chem. Soc. Rev. 2018, 47, 7190-7202. [CrossRef]

108. Zhou, Q.Q.; Zou, Y.Q.; Lu, L.Q.; Xiao, W.J. Visible-Light-Induced Organic Photochemical Reactions through Energy-Transfer Pathways. Angew. Chem. Int. Ed. 2019, 58, 1586-1604. [CrossRef]

109. Xiang, Y.; Kuang, Y.; Wu, J. Generation of Benzosultams via Trifluoromethylation of 2-Ethynylbenzenesulfonamide under Visible Light. Org. Chem. Front. 2016, 3, 901-905. [CrossRef]

110. Alcaide, B.; Almendros, P.; Busto, E.; Herrera, F.; Lázaro-Milla, C.; Luna, A. Photopromoted Entry to Benzothiophenes, Benzoselenophenes, 3H-Indoles, Isocoumarins, Benzosultams, and (Thio)flavones by Gold-Catalyzed Arylative Heterocyclization of Alkynes. Adv. Synth. Catal. 2017, 359, 2640-2652. [CrossRef]

111. Chen, F.; Yang, C.; Hu, X.; Zhang, X.; Xie, H.; Jiang, H.; Jiang, F.; Zeng, W. Photocatalyzed Formal Carbooxygenation of Terminal Alkynes. Org. Chem. Front. 2020, 7, 1600-1605. [CrossRef]

112. Zhao, Q.Q.; Hu, X.Q.; Yang, M.N.; Chen, J.R.; Xiao, W.J. A Visible-Light Photocatalytic N-Radical Cascade of Hydrazones for the Synthesis of Dihydropyrazole-Fused Benzosultams. Chem. Commun. 2016, 52, 12749-12752. [CrossRef] [PubMed]

(C) 2020 by the authors. Licensee MDPI, Basel, Switzerland. This article is an open access article distributed under the terms and conditions of the Creative Commons Attribution (CC BY) license (http://creativecommons.org/licenses/by/4.0/). 